\title{
Molecular probes for the human adenosine receptors
}

\author{
Xue Yang ${ }^{1} \cdot$ Laura H. Heitman ${ }^{1} \cdot$ Adriaan P. IJzerman ${ }^{1} \cdot$ Daan van der Es ${ }^{1}$ (i)
}

Received: 23 April 2020 / Accepted: 1 November 2020 / Published online: 12 December 2020

(C) The Author(s) 2020

\begin{abstract}
Adenosine receptors, G protein-coupled receptors (GPCRs) that are activated by the endogenous ligand adenosine, have been considered potential therapeutic targets in several disorders. To date however, only very few adenosine receptor modulators have made it to the market. Increased understanding of these receptors is required to improve the success rate of adenosine receptor drug discovery. To improve our understanding of receptor structure and function, over the past decades, a diverse array of molecular probes has been developed and applied. These probes, including radioactive or fluorescent moieties, have proven invaluable in GPCR research in general. Specifically for adenosine receptors, the development and application of covalent or reversible probes, whether radiolabeled or fluorescent, have been instrumental in the discovery of new chemical entities, the characterization and interrogation of adenosine receptor subtypes, and the study of adenosine receptor behavior in physiological and pathophysiological conditions. This review summarizes these applications, and also serves as an invitation to walk another mile to further improve probe characteristics and develop additional tags that allow the investigation of adenosine receptors and other GPCRs in even finer detail.
\end{abstract}

Keywords Probes · Adenosine receptors · GPCR - Chemical biology · Radioligands · PET ligands · Fluorescent ligands · Covalent ligands

\section{Introduction}

Adenosine receptors (ARs) belong to the class A family of $\mathrm{G}$ protein-coupled receptors (GPCRs) and are activated by their endogenous ligand adenosine. These receptors have been

This article is part of the Topical Collection on A Tribute to Professor Geoff Burnstock.

This review is dedicated to the memory of Prof Geoffrey Burnstock, who passed away on June 2, 2020. He has tirelessly advanced and promoted the research of purinoceptors, which the authors have greatly benefitted from over the years. Thanks, Geoff, for having been such an inspirational mentor.

Daan van der Es

d.van.der.es@lacdr.leidenuniv.nl

Xue Yang

x.yang.2@lacdr.leidenuniv.nl

Laura H. Heitman

1.h.heitman@lacdr.leidenuniv.nl

Adriaan P. IJzerman

ijzerman@lacdr.leidenuniv.nl

1 Division of Drug Discovery and Safety, Leiden Academic Centre for Drug Research, Leiden University, Einsteinweg 55, 2333

CC Leiden, The Netherlands considered potential therapeutic targets in several disorders, including Parkinson's disease, schizophrenia, analgesia, ischemia, and cancer [1]. To date, four subtypes of adenosine receptors have been identified, namely $A_{1}, A_{2 A}, A_{2 B}$, and $A_{3}$. Activation of $A_{1}$ and $A_{3}$ receptors leads to inhibition of adenylate cyclase through their interaction with a $\mathrm{G} \alpha_{i}$ protein, whereas $\mathrm{A}_{2 \mathrm{~A}}$ and $\mathrm{A}_{2 \mathrm{~B}}$ receptors stimulate the enzyme through a $\mathrm{G} \alpha_{\mathrm{S}}$-linked pathway. Until now, the $3 \mathrm{D}$ structures of the $\mathrm{A}_{1}$ and $\mathrm{A}_{2 \mathrm{~A}}$ subtypes have been elucidated [2,3]; structural studies on the $A_{2 B}$ and $A_{3}$ subtypes have yet to be successful. Crystallization of GPCRs, often a prerequisite for structural biology, still proves to be a challenging task due to their low expression in native tissue, and their inherent flexibility and instability once extracted from the membrane, which is needed for further structural studies. Over the past decades, a diverse array of molecular probes, bifunctional ligands that can be used to interrogate receptor structure and function, has proven invaluable in GPCR research. From a chemical perspective, a molecular probe can be defined as a small molecule that binds the receptor of interest and enables further studies by virtue of a connected tag or functional group that exhibits specific properties. These conjugated tags or functional groups include radioactive or fluorescent moieties to enable studies on ligand-receptor binding as well as the quantification and visualization of receptors. Moreover, tags containing 
a reactive warhead capable of irreversibly binding to the receptor have been shown to facilitate structure elucidation. When made bifunctional, i.e., combined with a click handle, these tags can be used as affinity-based probes (AfBPs), which are emerging as valuable tools for chemical biology or proteomics studies to gain further insight into receptor localization and target engagement [4-6]. This strategy was inspired by earlier activity-based protein profiling-click chemistry (ABPP-CC), which helped in visualizing and quantifying the activities of drug targets (mainly enzymes) in native biological systems $[7,8]$. In this review, various chemical probes for human adenosine receptors, comprising radioligands, fluorescent ligands, and covalent ligands, will be summarized.

\section{Radioligands for in vitro receptor characterization}

Some adenosine receptor agonists and antagonists have been developed in a radiolabeled ("hot") form, so-called radioligands. Often, these are high-affinity molecules containing radioactive isotopes such as $\left[{ }^{3} \mathrm{H}\right]-,\left[{ }^{125} \mathrm{I}\right]-$, and $\left[{ }^{35} \mathrm{~S}\right]-$, which emit radiation that can be detected and quantified. The majority of radioligands used for in vitro assays are labeled with either $\left[{ }^{125} \mathrm{I}\right]$ or $\left[{ }^{3} \mathrm{H}\right]$. While $\left[{ }^{125} \mathrm{I}\right]$-labeled ligands show a higher specific activity $(\sim 2000 \mathrm{Ci} / \mathrm{mmol})$ and shorter half-life $\left(t_{1 / 2}=60\right.$ days $)$ compared to tritium-labeled ligands (specific activity $\sim 25-120 \mathrm{Ci} / \mathrm{mmol}$ and $t_{1 / 2}=12.5$ years), $\left[{ }^{3} \mathrm{H}\right]$-labeled compounds are more biologically indistinguishable from the unlabeled parent ligand. These radiolabeled ligands are predominantly used in (i) saturation experiments to measure the radioligand's equilibrium dissociation constant, $K_{D}$, and receptor expression/density ( $B_{\max }$ ); in (ii) competition displacement experiments to determine the affinity (equilibrium inhibitory constant $K_{i}$ ) of non-labeled ("cold") compounds; and in (iii) binding kinetics assays to determine a ligand's association $\left(k_{\mathrm{on}}\right)$ and dissociation $\left(k_{\mathrm{off}}\right)$ rate constants $[9,10]$. Conventional radioligand binding assays require a filtration step to separate bound from unbound radiolabeled ligands and capture the radioligand-receptor complex. A more recently developed bead-based assay, the scintillation proximity assay (SPA), has emerged as a rapid and sensitive assay to perform high-throughput screens in a homogeneous system. Due to the diverse applicability of these techniques in receptor research, a diverse set of radioligands for the different AR subtypes has been developed. All radioligands that are currently commonly used are summarized in Table 1.

\section{Radioligands for the adenosine $A_{1}$ receptor}

Starting with agonist radioligands for $\mathrm{A}_{1} \mathrm{R}$, initially only tritiated adenosine-based derivatives were developed. Among them, $\left[{ }^{3} \mathrm{H}\right] \mathrm{CCPA}$ (Fig. 1; Table 1) showed the highest affinity with a $K_{D}$ value of $0.61 \mathrm{nM}$ for human $\mathrm{A}_{1} \mathrm{R}\left(\mathrm{hA}_{1} \mathrm{R}\right)$ [33]. $\left[{ }^{3} \mathrm{H}\right]$ LUF5834 is a non-nucleoside partial agonist radioligand (Fig. 1; Table 1) with nanomolar affinity $\left(K_{D}=2.03 \pm\right.$ $0.52 \mathrm{nM}$ ) for the $\mathrm{hA}_{1} \mathrm{R}$ [12]. Its partial agonistic nature allows this radioligand to bind to both $\mathrm{G}$ protein-coupled and uncoupled receptors. This radioligand proved a versatile tool to estimate the efficacy and the mechanism of action of both agonists and inverse agonists at the $\mathrm{hA}_{1} \mathrm{R}$.

The reference antagonist radioligand for $A_{1} R$ is the xanthine-derived antagonists/inverse agonist $\left[{ }^{3} \mathrm{H}\right] \mathrm{DPCPX}$ (Fig. 1; Table 1) [11]. Although this xanthine derivative displays lower affinity at the human $\left(K_{D}=3.86 \mathrm{nM}\right)$ [11] than the rat receptor $\left(K_{D}=0.18 \mathrm{nM}\right)$ [34], it is still a very useful tool for the characterization of $\mathrm{A}_{1} \mathrm{R}$ and to consequently discriminate from other subtypes. It has been applied in SPA technology, constituting an alternative platform for real-time measurements of receptor-ligand interactions on $\mathrm{hA}_{1} \mathrm{R}$ [35]. Antagonist radioligands, contrary to agonists, tend to label all receptors present in a cell membrane preparation independent of their coupling to a $\mathrm{G}$ protein and are therefore used more frequently in AR research, and GPCR research in general.

\section{Radioligands for the adenosine $A_{2 A}$ receptor}

The reference radioligands for binding assays at $\mathrm{A}_{2 \mathrm{~A}} \mathrm{R}$ include the adenosine-based agonists $\left[{ }^{3} \mathrm{H}\right] \mathrm{NECA}$ (Fig. 1; Table 1) [11] and $\left[{ }^{3} \mathrm{H}\right] \mathrm{CGS} 21680$ (Fig. 1; Table 1) [36]. While $\left[{ }^{3} \mathrm{H}\right] \mathrm{NECA}$ bound to $\mathrm{hA}_{2 \mathrm{~A}} \mathrm{R}$ with a $K_{D}$ value of $20 \mathrm{nM}$, this non-selective radioligand also exhibited remarkably high affinity for $\mathrm{hA}_{3} \mathrm{R}$ with a $K_{D}$ value of $6 \mathrm{nM}$, threefold higher than at the $\mathrm{A}_{2 \mathrm{~A}}$ receptor [11]. Later, the more selective radioligand $\left[{ }^{3} \mathrm{H}\right] \mathrm{CGS} 21680$ showed a moderate affinity for human $\mathrm{A}_{2 \mathrm{~A}} \mathrm{R}$ with a $K_{D}$ value of $22 \mathrm{nM}$ and has been used in autoradiographic studies, revealing the distribution of the $\mathrm{A}_{2 \mathrm{~A}} \mathrm{R}$ in the basal ganglia of the human brain and an increased $h \mathrm{~A}_{2 \mathrm{~A}} \mathrm{R}$ level in the striatum of schizophrenic patients [14, 37, 38]. However, besides its agonistic binding to high- and lowaffinity states of the receptor, application of this agonist radioligand is further limited due a limited selectivity over the $\mathrm{A}_{3} \mathrm{R}\left(K_{i}=67 \mathrm{nM}\right)$. This resulted in complex binding characteristics related to cortical, non- $\mathrm{A}_{2 \mathrm{~A}}$ binding sites [39].

To avoid the issues occurring with agonistic radioligands, two xanthine-based antagonist radioligands $\left[{ }^{3} \mathrm{H}\right] \mathrm{XAC}$ (Fig. 1; Table 1) [15] and $\left[{ }^{3} \mathrm{H}\right] \mathrm{MSX}-2$ (Fig. 1; Table 1) [16] were developed to investigate the $\mathrm{A}_{2 \mathrm{~A}} \mathrm{R}$. Although the unlabeled compound XAC showed poor selectivity for $h A_{2 A} \mathrm{R}$ over $\mathrm{hA}_{1} \mathrm{R}$ (30-fold) and $\mathrm{hA}_{3} \mathrm{R}$ (90-fold) [11], [ $\left.{ }^{3} \mathrm{H}\right] \mathrm{XAC}$ was used to label the $\mathrm{hA} \mathrm{A}_{2 \mathrm{~A}} \mathrm{R}$-binding pocket with a $K_{D}$ value of $9.4 \mathrm{nM}$ [15]. $\left.{ }^{3} \mathrm{H}\right] \mathrm{MSX}-2$ is a styrylxanthine-based antagonist which bound selectively to $\mathrm{rA}_{2 \mathrm{~A}} \mathrm{R}\left(K_{D}=8.0 \mathrm{nM}\right)$ [16]. Furthermore, in vitro autoradiography with $\left[{ }^{3} \mathrm{H}\right] \mathrm{MSX}-2$ showed the greatest binding in the striatum, which is in line with the expected 
Table 1 Commonly used AR radioligands for in vitro studies

\begin{tabular}{|c|c|c|c|c|}
\hline Radioligands & $K_{D}{ }^{\mathrm{a}}(\mathrm{nM})$ & Functionality & Refs & Commercially available \\
\hline \multicolumn{5}{|l|}{$A_{1}$} \\
\hline$\left[{ }^{3} \mathrm{H}\right] \mathrm{CCPA}$ & 0.61 & Agonist & {$[11]$} & $\mathrm{N}$ \\
\hline$\left[{ }^{3} \mathrm{H}\right] \mathrm{LUF5834}$ & 2.0 & Agonist & {$[12,13]$} & $\mathrm{N}$ \\
\hline$\left[{ }^{3} \mathrm{H}\right] \mathrm{DPCPX}$ & 3.9 & Antagonist & {$[11]$} & $\mathrm{Y}$ \\
\hline \multicolumn{5}{|l|}{$\mathrm{A}_{2 \mathrm{~A}}$} \\
\hline$\left[{ }^{3} \mathrm{H}\right] \mathrm{NECA}$ & 20 & Agonist & [11] & $\mathrm{Y}$ \\
\hline$\left[{ }^{3} \mathrm{H}\right] \mathrm{CGS} 21680$ & 22 & Agonist & {$[14]$} & $\mathrm{Y}$ \\
\hline$\left[{ }^{3} \mathrm{H}\right] \mathrm{XAC}$ & 9.4 & Antagonist & {$[15]$} & $\mathrm{N}$ \\
\hline$\left[{ }^{3} \mathrm{H}\right] \mathrm{MSX}-2$ & 8.0 & Antagonist & [16] & Y \\
\hline$\left[{ }^{3} \mathrm{H}\right] \mathrm{ZM} 241385$ & 0.60 & Antagonist & [17] & $\mathrm{Y}$ \\
\hline$\left[{ }^{3} \mathrm{H}\right] \mathrm{SCH} 58261$ & 2.3 & Antagonist & {$[18]$} & $\mathrm{Y}$ \\
\hline \multicolumn{5}{|l|}{$\mathrm{A}_{2 \mathrm{~B}}$} \\
\hline$\left[{ }^{3} \mathrm{H}\right] \mathrm{NECA}$ & 441 & Agonist & [19] & $\mathrm{Y}$ \\
\hline$\left[{ }^{3} \mathrm{H}\right] \mathrm{DPCPX}$ & 40 & Antagonist & [20] & Y \\
\hline$\left[{ }^{125} \mathrm{I}\right] \mathrm{I}-\mathrm{ABOPX}$ & 37 & Antagonist & {$[21]$} & $\mathrm{N}$ \\
\hline$\left[{ }^{3} \mathrm{H}\right] \mathrm{MRS} 1754$ & 1.1 & Antagonist & {$[22]$} & $\mathrm{Y}$ \\
\hline$\left[{ }^{3} \mathrm{H}\right] \mathrm{MRE}-2029-\mathrm{F} 20$ & 2.8 & Antagonist & {$[23]$} & $\mathrm{Y}$ \\
\hline$\left[{ }^{3} \mathrm{H}\right] \mathrm{OSIP} 339391$ & 0.17 & Antagonist & {$[24]$} & $\mathrm{N}$ \\
\hline$\left[{ }^{3} \mathrm{H}\right] \mathrm{PSB}-603$ & 0.40 & Antagonist & {$[25]$} & $\mathrm{N}$ \\
\hline \multicolumn{5}{|l|}{$\mathrm{A}_{3}$} \\
\hline$\left[{ }^{3} \mathrm{H}\right] \mathrm{NECA}$ & 6.2 & Agonist & [11] & $\mathrm{Y}$ \\
\hline${ }^{125}$ I-APNEA & $15(r)$ & Agonist & {$[26]$} & $\mathrm{N}$ \\
\hline$\left[{ }^{125} \mathrm{I}\right] \mathrm{I}-\mathrm{AB}-\mathrm{MECA}$ & 1.9 & Agonist & [27] & $\mathrm{Y}$ \\
\hline$\left[{ }^{3} \mathrm{H}\right] \mathrm{HEMADO}$ & 1.1 & Agonist & {$[28]$} & $\mathrm{Y}$ \\
\hline$\left[{ }^{125} \mathrm{I}\right] \mathrm{MRS} 1898$ & $0.17(\mathrm{r})$ & Agonist & [29] & $\mathrm{N}$ \\
\hline$\left[{ }^{125} \mathrm{I}\right] \mathrm{MRS} 5127$ & 5.7 & Partial agonist & [30] & $\mathrm{N}$ \\
\hline$\left[{ }^{3} \mathrm{H}\right] \mathrm{MRE}-3008-\mathrm{F} 20$ & 0.80 & Antagonist & {$[31]$} & $\mathrm{N}$ \\
\hline$\left[{ }^{3} \mathrm{H}\right] \mathrm{PSB}-11$ & 4.9 & Antagonist & {$[32]$} & $\mathrm{N}$ \\
\hline
\end{tabular}

${ }^{\text {a }}$ The data are $K_{D}$ values for radiolabeled compounds (nM) for the indicated human adenosine receptors unless a different species is indicated $(\mathrm{r}=$ rat $)$ density of $\mathrm{A}_{2 \mathrm{~A}} \mathrm{R}$ in the mouse, rat, and pig brains [40]. A preliminary ex vivo study confirmed that $\left[{ }^{3} \mathrm{H}\right] \mathrm{MSX}-2$ penetrated the blood-brain barrier, which is promising for in vivo use [40]. Applications of these styrylxanthine derivatives are limited however, due to the tendency to undergo photoinduced isomerization [41]. Meanwhile, two non-xanthine antagonist radioligands were developed as well. $\left[{ }^{3} \mathrm{H}\right] \mathrm{ZM} 241385$ (Fig. 1; Table 1) showed a high affinity and low non-specific binding to $\mathrm{hA}_{2 \mathrm{~A}} \mathrm{R}[17,42]$. However, this radioligand also binds to $\mathrm{A}_{2 \mathrm{~B}} \mathrm{R}$ with nanomolar affinity $\left(K_{D}=33.6 \mathrm{nM}\right)$ [43]. $\left[{ }^{3} \mathrm{H}\right] \mathrm{SCH} 58261$ (Fig. 1; Table 1) showed a better selectivity at the $\mathrm{hA} \mathrm{A}_{\mathrm{A}} \mathrm{R}\left(\mathrm{hA} \mathrm{A}_{2 \mathrm{~B}} / \mathrm{hA}_{2 \mathrm{~A}}=8352\right)$ than $\left[{ }^{3} \mathrm{H}\right] \mathrm{ZM} 241385$ and was used in autoradiographic studies to investigate the receptor distribution in the human brain [18, 37]. Similarly, $\left[{ }^{3} \mathrm{H}\right] \mathrm{SCH} 58261$ was applied in ex vivo binding studies to study $\mathrm{A}_{2 \mathrm{~A}} \mathrm{R}$ receptor occupancy of various ligands in mouse brain [44]. Additionally, this radioligand was applied in highthroughput ligand screening using a SPA setup and showed comparable sensitivity to the conventional filtration assay [45].

\section{Radioligands for the adenosine $A_{2 B}$ receptor}

So far only one selective agonist radioligand has been described for the $\mathrm{A}_{2 \mathrm{~B}} \mathrm{R}$, which is tritium-labeled BAY 60-6583 (Fig. 1; Table 1) [19]. Unfortunately, the specific binding of $\left[{ }^{3} \mathrm{H}\right] \mathrm{BAY}$ 60-6583 was too low compared to its high nonspecific binding to establish a robust radioligand binding assay. Until now, the non-selective agonist radioligand $\left[{ }^{3} \mathrm{H}\right] \mathrm{NECA}$, despite its low affinity, remains the only molecular tool available to specifically study the active $\mathrm{A}_{2 \mathrm{~B}} \mathrm{R}$ conformation $[19,46]$.

The $\mathrm{A}_{1} \mathrm{R}$ radioligand $\left[{ }^{3} \mathrm{H}\right] \mathrm{DPCPX}$ (Fig. 1; Table 1) was also reported to bind $\mathrm{hA}_{2 \mathrm{~B}} \mathrm{R}\left(K_{D}=40 \mathrm{nM}\right)$ and has been used to determine the affinity of competing ligands [20,47]. Another non-selective radioligand is $\left[{ }^{125} \mathrm{I}\right] \mathrm{I}-\mathrm{ABOPX}$ (Fig. 1, 


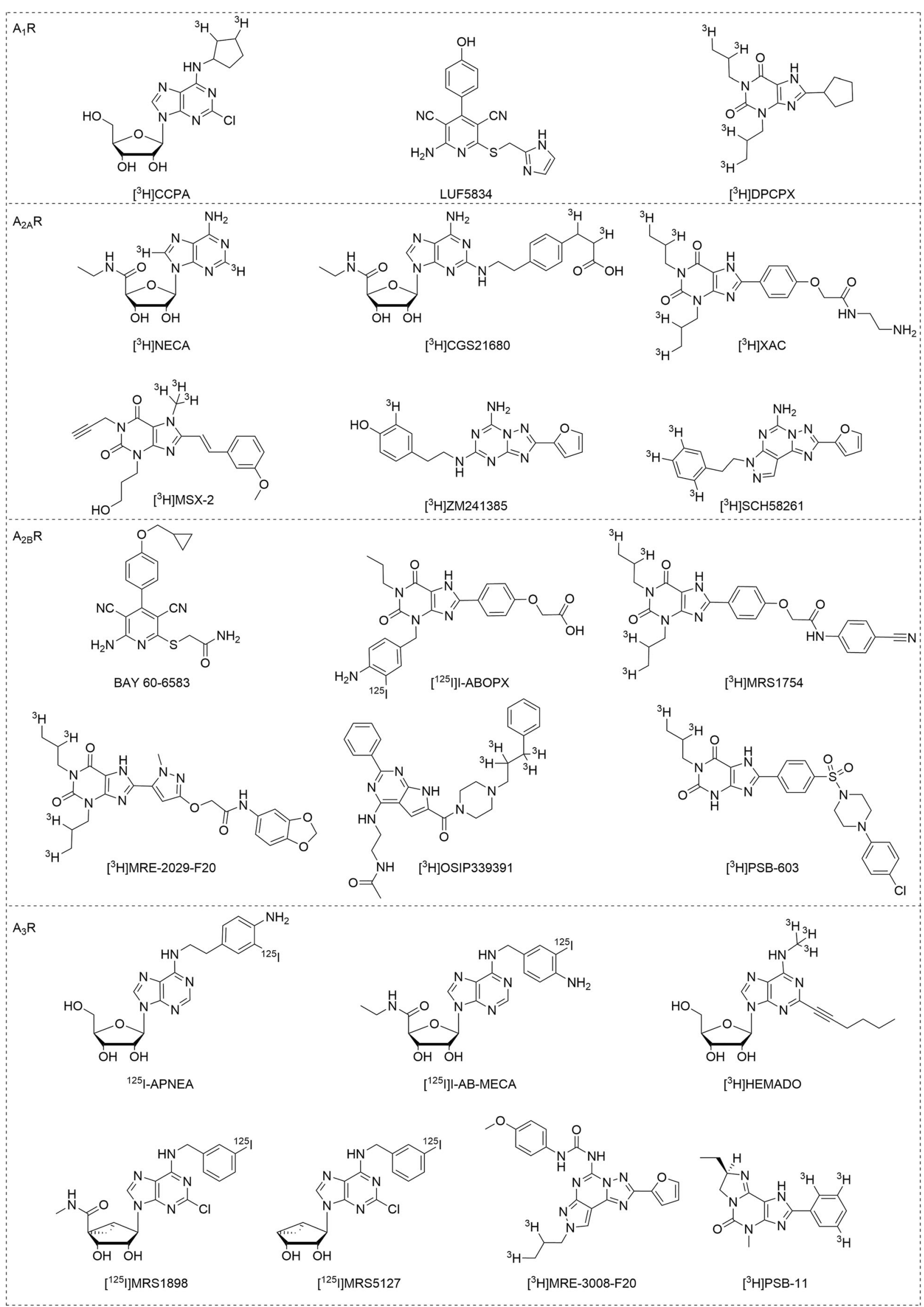


Fig. 1 Chemical structures of commonly used AR radioligands for in vitro studies. Unlabeled version was drawn for radioligands with unknown radioisotope position (i.e., $\left[{ }^{3} \mathrm{H}\right]$ LUF5834 and $\left[{ }^{3} \mathrm{H}\right] \mathrm{BAY}$ 60-6583)

Table 1) [21], which bound to $\mathrm{A}_{2 \mathrm{~B}} \mathrm{R}$ with moderate affinity $\left(K_{D}=37 \mathrm{nM}\right)$ and showed a high specific binding to a $\mathrm{hA}{ }_{2 \mathrm{~B}} \mathrm{R}$ overexpressing cell line. The first $\mathrm{A}_{2 \mathrm{~B}} \mathrm{R}$-selective antagonist radioligand reported was $\left[{ }^{3} \mathrm{H}\right] \mathrm{MRS} 1754$ (Fig. 1; Table 1), which bound to $\mathrm{hA}_{2 \mathrm{~B}} \mathrm{R}$ with a $K_{D}$ value of $1.1 \mathrm{nM}$ [22]. Later, another xanthine analog radioligand $\left[{ }^{3} \mathrm{H}\right] \mathrm{MRE}-2029$ F20 was reported with comparable affinity and selectivity $[23,48]$. The pyrrolopyrimidine-derivative OSIP339391 (Fig. 1; Table 1) was also labeled with tritium, representing a novel selective and high-affinity radioligand for the $h \mathrm{~A}_{2 \mathrm{~B}} \mathrm{R}$ [24]. However, all these radioligands showed poor selectivity (less than 100-fold) towards the $\mathrm{hA}_{1} \mathrm{R}$. More recently, Müller et al. investigated the structure-activity relationships of 1-alkyl-8-(piperazine-1-sulfonyl)phenylxanthine derivatives, yielding a new and potent $\mathrm{A}_{2 \mathrm{~B}}$-selective antagonist, PSB603 [25]. Tritium-labeled PSB-603 (Fig. 1; Table 1) was subsequently developed and employed as the first high-affinity $\left(K_{D}=0.40 \mathrm{nM}\right) \mathrm{A}_{2 \mathrm{~B}} \mathrm{R}$-specific radioligand for receptor pharmacological studies. However, the current xanthine-based radioactive tracers are highly lipophilic compounds that exhibit unfavorable non-specific to specific binding ratios; this feature confines their application to receptor studies in isolated membranes.

\section{Radioligands for the adenosine $A_{3}$ receptor}

Initially, studies on the human $\mathrm{A}_{3} \mathrm{R}\left(\mathrm{hA_{3 }} \mathrm{R}\right)$ were performed using the non-selective agonist radioligand $\left[{ }^{3} \mathrm{H}\right]$ NECA (Fig. 1, Table 1) [11]. For binding studies on the rat $A_{3} R\left(\mathrm{rA}_{3} \mathrm{R}\right)$ however, ${ }^{125}$ I-APNEA (Fig. 1, Table 1) was the preferred radioligand [49]. Although ${ }^{125}$ I-APNEA showed reasonable affinity for the $\mathrm{rA}_{3} \mathrm{R}\left(K_{D}=15 \mathrm{nM}\right)$, it was shown to be even more potent for the $\mathrm{rA}_{1} \mathrm{R}\left(K_{D}=1.3 \mathrm{nM}\right)[26,49]$. Another agonist radioligand, $\left[{ }^{125} \mathrm{I}\right] \mathrm{I}-\mathrm{AB}-\mathrm{MECA}$ (Fig. 1; Table 1), showed better affinities for both $\mathrm{rA}_{3} \mathrm{R}\left(K_{D}=1.5 \mathrm{nM}\right)$ and $\mathrm{hA}_{3} \mathrm{R}\left(K_{D}=1.9 \mathrm{nM}\right)[26,27]$, but still bound to $\mathrm{rA}_{1} \mathrm{R}$ in the nanomolar range $\left(K_{D}=3.4 \mathrm{nM}\right)$ [26]. To tackle the selectivity challenge, Klotz et al. developed the tritiated agonist radioligand $\left[{ }^{3} \mathrm{H}\right]$ HEMADO (Fig. 1, Table 1) [28], which showed high-affinity $\left(K_{D}=1.1 \mathrm{nM}\right)$ and low non-specific binding (1-2\% at $K_{D}$ value) to $\mathrm{hA}_{3} \mathrm{R}$. Even though no binding on the rat $\mathrm{rA}_{3} \mathrm{R}$ was observed, the enhanced selectivity versus other AR subtypes ( $>300$ fold) made $\left[{ }^{3} \mathrm{H}\right]$ HEMADO a useful tool for $\mathrm{A}_{3} \mathrm{R}$ binding assays. Subsequent efforts in finding a selective ligand for the $\mathrm{rA}_{3} \mathrm{R}$ resulted in $\left[{ }^{125} \mathrm{I}\right] \mathrm{MRS} 1898$ (Fig. 1 ; Table 1), which selectively binds to $\mathrm{rA}_{3} \mathrm{R}$ with an improved $K_{D}$ value of $0.17 \mathrm{nM}$ [29]. Still, there are some liabilities caused by the high non-specific binding. The truncation of the $5^{\prime}$-position of the ribose moiety generated the latest $A_{3} R$ agonist radioligand $\left.{ }^{125} \mathrm{I}\right] \mathrm{MRS} 5127$ (Fig. 1; Table 1) with a $K_{D}$ value of $5.7 \mathrm{nM}[30]$. Its major advantage is the low degree of non-specific binding ( $27 \pm 2 \%$ at a concentration of $5 \mathrm{nM})$ and its improved selectivity versus the other AR subtypes. These benefits, together with the uniformity of its agonistic nature across species, may render $\left[{ }^{125} \mathrm{I}\right] \mathrm{MRS} 5127$ the preferred chemical tool for characterizing the $A_{3} R$ in its active state over other radioligands reported previously. Commercially available $\left[{ }^{125} \mathrm{I}\right] \mathrm{I}-\mathrm{AB}-\mathrm{MECA}$ has emerged as a reference radioligand though.

Until now, only two antagonist radioligands, $\left[{ }^{3} \mathrm{H}\right] \mathrm{MRE}-$ 3008-F20 (Fig. 1; Table 1) [31, 50] and $\left[{ }^{3} \mathrm{H}\right] \mathrm{PSB}-11$ (Fig. 1; Table 1) [32], have been reported for the $A_{3} R$. While both derivatives selectively bind the $\mathrm{hA}_{3} \mathrm{R}$ at (sub)nanomolar concentrations, $\left[{ }^{3} \mathrm{H}\right] \mathrm{PSB}-11$ shows a much lower degree of nonspecific binding $\left(2.5 \pm 0.1 \%\right.$ at $K_{D}$ value $)$ than $\left[{ }^{3} \mathrm{H}\right] \mathrm{MRE}-$ 3008 -F20 (ca. $25 \%$ at $K_{D}$ value). The downside of these structurally diverse heterocyclic antagonists is their low affinity for the $\mathrm{A}_{3} \mathrm{R}$ in non-human, particularly rodent tissue.

\section{Radioligands for in vivo studies-PET/SPECT tracers}

While $\beta$-emitting ligands serve their purpose in in vitro or ex vivo experiments, they are not suitable for in vivo application. To that end, positron emission tomography (PET) and single-photon emission computed tomography (SPECT) scanning have emerged and are noninvasive quantitative techniques to measure the receptor distribution and function in vivo. Over the years, an ever-expanding library of $\left[{ }^{11} \mathrm{C}\right]-$, $\left[{ }^{18} \mathrm{~F}\right]$-, and $\left[{ }^{123} \mathrm{I}\right]$-labeled radiotracers has been developed that enables the determination of receptor binding potentials (BPs) in physiological and pathophysiological studies. Although the decay of these isotopes is much faster than is the case for $\left[{ }^{3} \mathrm{H}\right]$ or $\left[{ }^{125} \mathrm{I}\right]$-labeled ligands, the relatively safe $\gamma$ - and photonemissions make these tracers suitable for physiological applications. SPECT radioisotopes, such as $\gamma$-emitting $\left[{ }^{123} \mathrm{I}\right]\left(t_{1 / 2}=\right.$ $13.2 \mathrm{~h}$ ), typically have a much longer half-life than PET tracers labeled with $\left[{ }^{11} \mathrm{C}\right]\left(t_{1 / 2}=20.3 \mathrm{~min}\right)$ or $\left[{ }^{18} \mathrm{~F}\right]\left(t_{1 / 2}=\right.$ $110 \mathrm{~min}$ ), which allow for longer radiosynthetic protocols and enable SPECT imaging to be conducted for longer time periods. Nonetheless, PET studies of adenosine receptors have been more widely performed due to the higher resolution and sensitivity that can generally be achieved compared to SPECT. In the development of radiotracers for ARs, particularly in the brain and central nervous system, it is desirable to not only optimize for affinity and low non-specific binding capacity, but also for blood-brain barrier permeability. A major challenge is that the short radioligand half-life requires onsite synthesis and rapid purification and validation of the probes. PET and SPECT imaging times, which are also related 
to radioligand $t_{1 / 2}$, are usually insufficient to allow radioligand-receptor binding to reach an equilibrium; therefore, appropriate kinetic models should be used to correct for this shortcoming. PET imaging of ARs in vivo and the applications thereof in drug discovery have been comprehensively reviewed [51-53]. Here, we will focus on the recent applications of clinical PET imaging studies on ARs.

\section{PET tracers for the adenosine $A_{1}$ receptor}

Two xanthine derivatives, $\left[{ }^{18}\right.$ F $]$ CPFPX (Fig. 2, Table 2) and $\left[{ }^{11} \mathrm{C}\right]$ MPDX (Fig. 2, Table 2), have been extensively employed for the characterization of $A_{1} R$ in human brain, and their results are summarized in several reviews $[51,65]$. While $\left[{ }^{18} \mathrm{~F}\right] \mathrm{CPFPX}$ has a higher affinity for $\mathrm{A}_{1} \mathrm{R}$ than $\left[{ }^{11} \mathrm{C}\right] M P D X$, the latter has been shown to be much more stable against peripheral metabolism. Using these PET tracers, the cerebral distribution of the $A_{1} R$ has been successfully visualized and quantified in human brain [66, 67]. From these studies, a correlation between $\mathrm{A}_{1} \mathrm{R}$ distribution and aging as well as sleep deprivation was established $[68,69]$. Additional studies on receptor occupancy using PET tracers, for example $\left[{ }^{18} \mathrm{~F}\right] \mathrm{CPFPX}$ in a bolus-plus-constant-infusion PET assay, showed that repeated intake of caffeinated beverages resulted in a 50\% occupancy of the cerebral $A_{1}$ Rs during the day [70]. This effect might cause adaptive changes and lead to chronic alterations of receptor expression and availability. Furthermore, these PET tracers have been valuable tools for clinical studies on neurodegenerative diseases, revealing the functional mechanisms and pharmacokinetic profiles of new potential drug treatment strategies. In early Parkinson's disease, increased binding of $\left[{ }^{11} \mathrm{C}\right] \mathrm{MPDX}$ was found in the temporal lobe, suggesting a compensatory mechanism of $A_{1} R$ expression in non-dopaminergic systems in response to the diminished availability of dopamine [71]. With $\left[{ }^{18} \mathrm{~F}\right] \mathrm{CPFPX}$, a phase- and region-specific pattern of $\mathrm{A}_{1} \mathrm{R}$ expression in Huntington's disease was detected, providing evidence that adenosinergic targets are involved in the pathophysiology of this disease [72]. More recently, the first partial agonist PET tracer, $\left[{ }^{11} \mathrm{C}\right]$ MMPD (Fig. 2, Table 2), was evaluated in rat brain [54]. It showed suitable blood-brain barrier (BBB) permeability, high specificity, and subtype selectivity in vivo. This finding may open new routes to visualize receptor occupancy of agonists or partial agonists at the $A_{1} R$ in drug development.

\section{PET/SPECT tracers for the adenosine $A_{2 A}$ receptor}

Several radioligands for PET imaging of cerebral $\mathrm{A}_{2 \mathrm{~A}}$ Rs have been introduced since the 1990s. The initial design of PET tracers for the $\mathrm{A}_{2 \mathrm{~A}} \mathrm{R}$ started from xanthine-based antagonists, leading to the discovery of $\left[{ }^{11} \mathrm{C}\right] \mathrm{TMSX}$ (Fig. 2, Table 2), previously abbreviated as $\left[{ }^{11} \mathrm{C}\right] \mathrm{KF} 18446$. Though in vivo imaging of the human brain in healthy controls and in patients with Parkinson's disease (PD) was relatively successful [73, 74], these xanthine derivatives are prone to photoisomerization, and thus $\left[{ }^{11} \mathrm{C}\right] \mathrm{TMSX}$ could only be applied in PET scans under dimmed light. To circumvent this limitation, the first non-xanthine-based PET tracer, $\left[{ }^{11} \mathrm{C}\right] \mathrm{SCH} 442416$ (Fig. 2, Table 2), was designed based on a known precursor, SCH58261. An increased binding potential of $\left[{ }^{11} \mathrm{C}\right] \mathrm{SCH} 442416$ was observed in the striatum of Parkinson's patients with levodopa-induced dyskinesias (LIDs), providing evidence that $\mathrm{A}_{2 \mathrm{~A}} \mathrm{R}$ is a potential pharmacological target for the management of LIDs [75]. Since the problem of high non-specific binding (and consequential low target-to-non-target ratios) still remains for these ligands [76], Zhou et al. incorporated the ${ }^{11} \mathrm{C}$-radionuclide into clinical candidate preladenant. PET imaging in rats showed a high uptake of $\left[{ }^{11} \mathrm{C}\right]$ preladenant (Fig. 2, Table 2) in the striatum and low uptake in other regions of the brain, consistent with cerebral $\mathrm{A}_{2 \mathrm{~A}}$ distribution [77]. Using $\left[{ }^{11} \mathrm{C}\right]$ preladenant in clinical PET studies, receptor occupancy by istradefylline, an approved $A_{2 A} R$ antagonist, was measured in patients with Parkinson's disease. It was demonstrated that istradefylline binds to $\mathrm{A}_{2 \mathrm{~A}} \mathrm{R}$ in a dose-dependent manner, consequently resulting in near-maximal (94\%) occupancy in the ventral striatum, thus establishing the dosage regimen of such CNS drugs [78]. Subsequently, to benefit from the prolonged halflife of these tracers, ${ }^{18} \mathrm{~F}$-labeled $\mathrm{A}_{2 \mathrm{~A}} \mathrm{R}$ antagonist PET tracers have been investigated for human studies. For example, two fluorine-18 labeled SCH442416 analogs, $\left[{ }^{18} \mathrm{~F}\right] \mathrm{FESCH}$ (Fig. 2, Table 2) and $\left[{ }^{18} \mathrm{~F}\right]$ FPSCH (Fig. 2, Table 2), were reported as PET tracers used to image the $\mathrm{A}_{2 \mathrm{~A}} \mathrm{R}$ in rat brain [79]. $\left[{ }^{18} \mathrm{~F}\right] \mathrm{FESCH}$ and $\left[{ }^{18} \mathrm{~F}\right] \mathrm{FPSCH}$ showed identical striatum-tocerebellum ratios (4.6 at $37 \mathrm{~min}$ and $25 \mathrm{~min}$ post-injection, respectively), similar to the ratio obtained with $\left[{ }^{11} \mathrm{C}\right] \mathrm{SCH} 442416$. Other examples are preladenant-based ligands, including a SPECT tracer, $\left[{ }^{123} \mathrm{I}\right] \mathrm{MNI}-420$ (Fig. 2, Table 2), and a PET ligand, $\left[{ }^{18} \mathrm{~F}\right] \mathrm{MNI}-444$ (Fig. 2, Table 2). Both have been successfully applied in $\mathrm{A}_{2 \mathrm{~A}} \mathrm{R}$ imaging studies in the human brain $\left.[80,81] .{ }^{123} \mathrm{I}\right] \mathrm{MNI}-420$ rapidly entered the human brain and showed the highest specific binding in the striatum, consistent with known $\mathrm{A}_{2 \mathrm{~A}} \mathrm{R}$ densities. $\left[{ }^{18} \mathrm{~F}\right] \mathrm{MNI}-$ 444 showed an improved binding potential in the brain compared to $\left[{ }^{11} \mathrm{C}\right] \mathrm{TMSX}$ and $\left[{ }^{11} \mathrm{C}\right] \mathrm{SCH} 442416$, opening up the possibility to more broadly use in vivo $\mathrm{A}_{2 \mathrm{~A}}$ PET imaging in neuroscience research.

\section{PET tracers for the adenosine $A_{2 B}$ receptor}

So far only two radioligands for use in in vivo studies have been developed for $\mathrm{A}_{2 \mathrm{~B}} \mathrm{R}$, namely 1-[ $\left.{ }^{11} \mathrm{C}\right]$ "4" (Fig. 2, Table 2) and $-\left[{ }^{18} \mathrm{~F}\right] " 7 \mathrm{a}$ " (Fig. 2, Table 2) [61, 62]. The first compound, featuring a triazinobenzimidazole scaffold with moderate potency $\left(\mathrm{IC}_{50}=210.2 \pm 12.3 \mathrm{nM}\right)$ towards $\mathrm{A}_{2 \mathrm{~B}} \mathrm{R}$, has been 
applied in PET studies in rats and showed the highest uptake in brown adipose tissue, lungs, and testes [61]. With a high chemical stability and good pharmacokinetic profile, this tool compound represented a good lead for the development of $\mathrm{A}_{2 \mathrm{~B}} \mathrm{R}$ radiotracers. The second $\mathrm{A}_{2 \mathrm{~B}} \mathrm{R}$ PET tracer was developed on a pyrazine-based antagonist with the potential to penetrate the blood-brain barrier [62]. Despite poor selectivity $\left(\mathrm{A}_{2 \mathrm{~A}} / \mathrm{A}_{2 \mathrm{~B}}=13, \mathrm{~A}_{1} / \mathrm{A}_{2 \mathrm{~B}}=5\right)$, this radiolabeled ligand was further evaluated for its in vivo pharmacokinetic profile, revealing the formation of a radio-metabolite capable of penetrating the blood-brain barrier. With these PET studies, the stage is set for further $A_{2 B} R$ probe design to enhance their selectivity and metabolic stability.

\section{PET tracers for the adenosine $A_{3}$ receptor}

The first PET tracer for $\mathrm{A}_{3} \mathrm{R}$ was developed by radiofluorination of FE@SUPPY (Fig. 2, Table 2), a selective and potent antagonist for $\mathrm{hA}_{3} \mathrm{R}[82,83]$. Although it had already been shown for the parent compound that the affinity for rat $A_{3} R$ was 140-fold lower than for human $A_{3} R$, $\left[{ }^{18} \mathrm{~F}\right] \mathrm{FE} @$ SUPPY was studied for its biodistribution in rats, and specific binding in the rat brain was demonstrated using autoradiography [83]. A further preclinical PET study using $\left[{ }^{18} \mathrm{~F}\right]$ FE@SUPPY to image $\mathrm{A}_{3} \mathrm{R}$ revealed a pronounced uptake in xenografted mice injected with cells overexpressing human $\mathrm{A}_{3} \mathrm{R}$. This "humanized animal model" inspired to evaluate $\left[{ }^{18} \mathrm{~F}\right] \mathrm{FE} @ S U P P Y$ in mice xenografted with a human colorectal cancer cell line (HT-29) overexpressing $A_{3} R$ as a tumor marker. Unfortunately, this study to visualize the $A_{3} R$ in vivo was unsuccessful, presumably due to insufficient uptake of $\left[{ }^{18} \mathrm{~F}\right] \mathrm{FE} @$ SUPPY in the tumors, poor conservation of target expression in xenografts, or unfavorable pharmacokinetics of the tracer in mice [63]. In analogy to this, $\left[{ }^{18} \mathrm{~F}\right]$ FE@SUPPY:2 (Fig. 2, Table 2) was developed by transforming the fluoroethylester into a fluoroethylthioester [84]. While a higher specific radioactivity was obtained ( $\left[{ }^{18} \mathrm{~F}\right] \mathrm{FE} @ \mathrm{SUPPY}: 2=340 \pm 140 \mathrm{GBq} / \mathrm{mol}$ and $\left.\left[{ }^{18} \mathrm{~F}\right] \mathrm{FE} @ \mathrm{SUPPY}=70 \pm 26 \mathrm{GBq} / \mathrm{mol}\right)$, the uptake pattern for the two PET tracers is distinct. Especially, brain to blood ratios are remarkably increased over time for $\left[{ }^{18} \mathrm{~F}\right] \mathrm{FE} @ \mathrm{SUPPY}$, whereas those for $\left[{ }^{18} \mathrm{~F}\right] \mathrm{FE} @ \mathrm{SUPPY}: 2$ stayed unaltered. Lastly, a pair of structurally similar ligands (i.e., agonist MRS3581 and antagonist MRS5147) were reported as $\left[{ }^{76} \mathrm{Br}\right]$-labeled potential PET radiotracers [64]. Both ligands showed similar biodistribution in rats, i.e., primarily uptake in the organs of metabolism and excretion. However, the uptake of agonist $\left[{ }^{76} \mathrm{Br}\right] \mathrm{MRS} 3581$ (Fig. 2, Table 2) was an order of magnitude faster than that of antagonist $\left[{ }^{76} \mathrm{Br}\right] \mathrm{MRS} 5147$ (Fig. 2, Table 2), possibly due to the presence of a uronamide group in the agonist to influence its bioavailability and permeation in vivo. In contrast, the antagonist $\left[{ }^{76} \mathrm{Br}\right] \mathrm{MRS} 5147$ demonstrated an increased uptake in rat testes, an $\mathrm{A}_{3} \mathrm{R}$-rich tissue, suggesting that the antagonist may also serve as a viable diagnostic molecular probe for pathological conditions with increased $\mathrm{A}_{3} \mathrm{R}$ expression.

\section{Fluorescent probes}

As an alternative to radiolabeled molecular probes, fluorescent ligands have also been included into the pharmacological toolbox. This approach avoids the safety concerns associated with the disposal of radioisotopes and also provides the opportunity of a "real-time" readout of the ligand-receptor interaction. Fluorescent ligands for GPCRs are usually designed by incorporating an organic fluorophore, such as a BODIPY, AlexaFluor ${ }^{\circledR}$, rhodamine, or NBD (nitrobenzoxadiazole) moiety into an existing GPCR agonist or antagonist pharmacophore via a linker. The use of these fluorescent probes in GPCR research has recently been reviewed [85] and includes studies on receptor localization, function, and regulation, but also on ligand-target binding kinetics, thus contributing to a detailed understanding of receptor physiology and pathophysiology. In addition, the development of newer methods and techniques, such as scanning confocal microscopy, fluorescence polarization, fluorescence correlation spectroscopy, resonance energy transfer (FRET or BRET), and flow cytometry, is boosting the potential use of fluorescent probes in drug discovery. The development of fluorescent ligands to characterize adenosine receptors has been the subject of intense investigation, which has been summarized in detail by Kozma et al. in 2013 [86]. Here, we will therefore summarize and review emerging fluorescent ligands for more recent applications on ARs.

\section{Fluorescent ligands for the adenosine $A_{1}$ receptor}

To monitor ligand binding to receptors on the surface of living cells, a nano-luciferase (NanoLuc) BRET methodology (NanoBRET) has recently been established [87-89]. This approach was also applied to a study of allosteric modulators in intact living cells using fluorescent $A_{1} R$ agonists, such as the adenosine-based agonist, ABA-X-BY630 (Fig. 3, Table 3), and two NECA-based ligands, ABEA-X-BY630 (Fig. 3, Table 3) and BY630-X-(D)-A-(D)-A-G-ABEA (Fig. 3, Table 3) [90]. The two positive allosteric modulators tested were shown to increase the specific binding of the fluorescent $A_{1} R$ agonists, indicative for a switch of the $A_{1} R$ population to a more active receptor conformation.

\section{Fluorescent ligands for the adenosine $A_{2 A}$ receptor}

MRS5424 (Fig. 3, Table 3) is a fluorescent adduct of agonist APEC with AlexaFluor ${ }^{\circledR 532}$. Using this probe, allosteric modulation within $A_{2 A} R / D_{2} R$ heterodimers was followed 


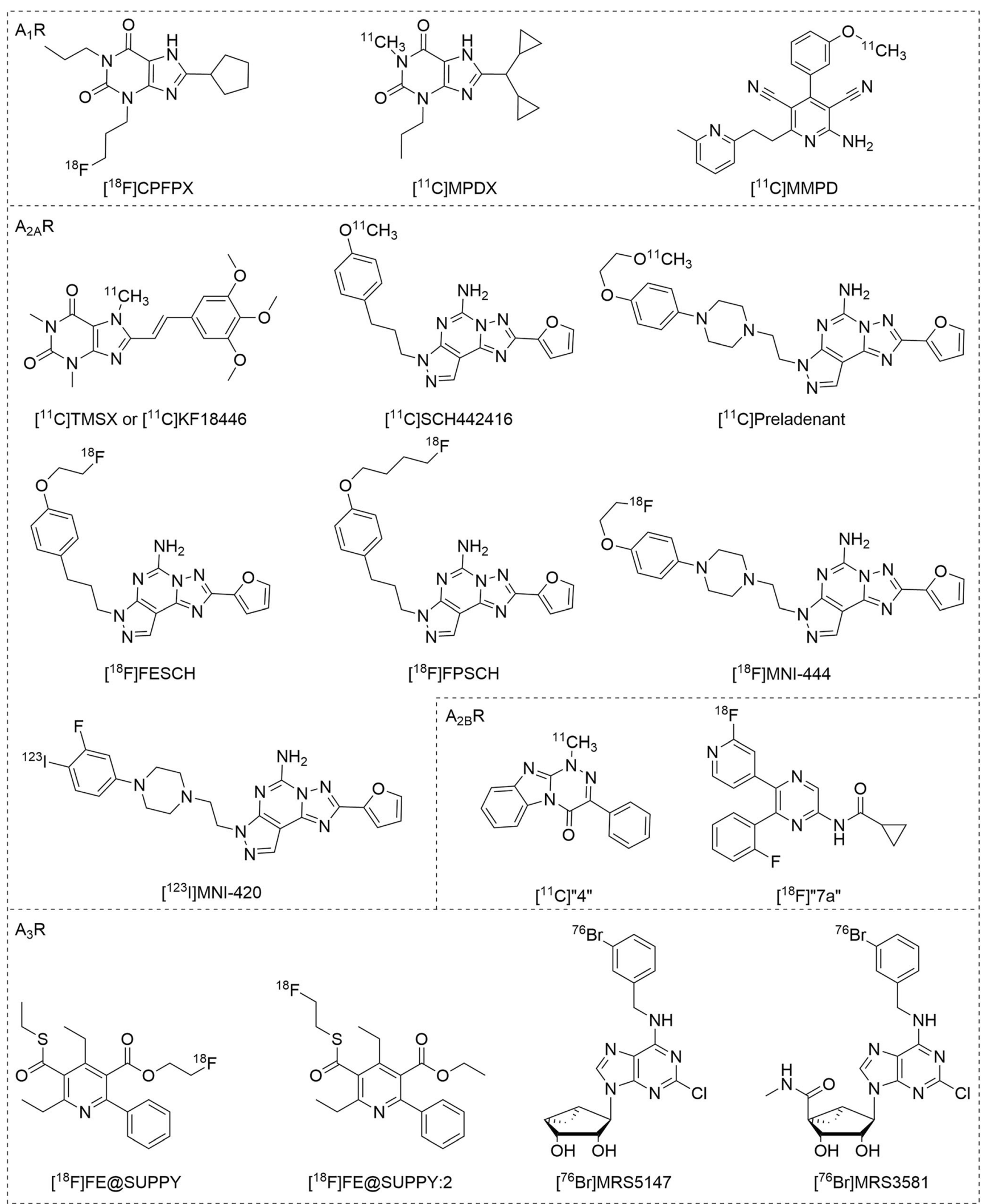

Fig. 2 Chemical structures of AR radioligand tracers for in vivo studies

using real-time FRET [101]. A negative allosteric effect on $\mathrm{A}_{2 \mathrm{~A}} \mathrm{R}$ ligand binding and receptor activation was found when the $\mathrm{D}_{2} \mathrm{R}$ agonist quinpirole was added. This heterodimer interaction was further validated in a higher-throughput flow 
Table 2 Recent AR radioligands used for clinical PET or SPECT imaging

\begin{tabular}{|c|c|c|c|c|c|c|}
\hline \multirow[t]{2}{*}{ Radioligands } & \multicolumn{4}{|l|}{$K_{D}(\mathrm{nM})^{\mathrm{a}}$} & \multirow[t]{2}{*}{ Functionality } & \multirow[t]{2}{*}{ Ref } \\
\hline & $\mathrm{A}_{1}$ & $\mathrm{~A}_{2 \mathrm{~A}}$ & $\mathrm{~A}_{2 \mathrm{~B}}$ & $\mathrm{~A}_{3}$ & & \\
\hline \multicolumn{7}{|l|}{$\mathrm{A}_{1}$} \\
\hline$\left[{ }^{18} \mathrm{~F}\right] \mathrm{CPFPX}$ & 1.3 & 940 & N.D. & N.D. & Antagonist & [51] \\
\hline$\left[{ }^{11} \mathrm{C}\right] \mathrm{MPDX}$ & $4.2(\mathrm{r})$ & $>100(\mathrm{r})$ & N.D. & N.D. & Antagonist & [51] \\
\hline$\left[{ }^{11} \mathrm{C}\right] \mathrm{MMPD}$ & 0.5 & 71 & 75 & $42 \%(1 \mu \mathrm{M})$ & Partial agonist & [54] \\
\hline \multicolumn{7}{|l|}{$\mathrm{A}_{2 \mathrm{~A}}$} \\
\hline$\left[{ }^{11} \mathrm{C}\right] \mathrm{TMSX}$ or $\left[{ }^{11} \mathrm{C}\right] \mathrm{KF} 18446$ & $1600(\mathrm{r})$ & $5.9(\mathrm{r})$ & N.D. & N.D. & Antagonist & {$[55]$} \\
\hline$\left[{ }^{11} \mathrm{C}\right] \mathrm{SCH} 442416$ & 1.1 & 0.05 & $>10,000$ & $>10,000$ & Antagonist & {$[56]$} \\
\hline$\left[{ }^{11} \mathrm{C}\right]$ preladenant & $>1000$ & 1.1 & $>1700$ & $>1000$ & Antagonist & [57] \\
\hline$\left[{ }^{18} \mathrm{~F}\right] \mathrm{FESCH}$ & $43 \%(10 \mu \mathrm{M})$ & 12 & N.D. & $60 \%(10 \mu \mathrm{M})$ & Antagonist & {$[58]$} \\
\hline$\left[{ }^{18} \mathrm{~F}\right] \mathrm{FPSCH}$ & 1000 & 54 & N.D. & 1320 & Antagonist & [59] \\
\hline$\left[{ }^{18} \mathrm{~F}\right] \mathrm{MNI}-444$ & N.D. & 2.8 & N.D. & N.D. & Antagonist & {$[60]$} \\
\hline$\left[{ }^{123} \mathrm{I}\right] \mathrm{MNI}-420$ & N.D. & 2.0 & N.D. & N.D. & Antagonist & {$[60]$} \\
\hline \multicolumn{7}{|l|}{$\mathrm{A}_{2 \mathrm{~B}}$} \\
\hline$\left[{ }^{11} \mathrm{C}\right] " 4 "$ & 230 & 548 & 210 & N.A. & Antagonist & [61] \\
\hline$\left.\left[{ }^{18} \mathrm{~F}\right]\right]^{\prime} 7 \mathrm{a} "$ & 19 & 55 & 4.2 & 796 & Antagonist & [62] \\
\hline \multicolumn{7}{|l|}{$\mathrm{A}_{3}$} \\
\hline$\left[{ }^{18} \mathrm{~F}\right] \mathrm{FE} @ S U P P Y$ & 4030 & 1720 & N.D. & 6.0 & Antagonist & [63] \\
\hline$\left[{ }^{76} \mathrm{Br}\right] \mathrm{MRS} 3581$ & N.D. & N.D. & N.D. & 0.63 & Agonist & [64] \\
\hline$\left[{ }^{76} \mathrm{Br}\right] \mathrm{MRS} 5147$ & N.D. & N.D. & N.D. & 0.62 & Antagonist & [64] \\
\hline
\end{tabular}

N.D. not determined, N.A. not active

${ }^{\text {a }}$ The data are $K_{D}$ values of radiolabeled compounds for human adenosine receptors unless otherwise indicated ( $\mathrm{r}=$ rat) or $\%$ inhibition at the indicated concentration in brackets

cytometry-based assay with the fluorescent agonist MRS5206 (APEC-AlexaFluor® 488) (Fig. 3, Table 3) [102]. These experiments provided evidence for a differential $\mathrm{D}_{2} \mathrm{R}$-mediated negative allosteric modulation of $\mathrm{A}_{2 \mathrm{~A}} \mathrm{R}$ agonist binding, in particular for apomorphine, a drug used in the treatment of PD. Recently, using a fluorescence polarization assay, McNeely et al. employed a fluorescent agonist, FITCAPEC (Fig. 3, Table 3), to characterize the binding kinetics of three $h A_{2 A} R$ ligands $[91,92]$. The kinetic parameters of these unlabeled ligands, computed using a numerical solution approach, showed good consistency with those determined in a conventional radioligand binding assay.

Endeavors to enhance selectivity towards $\mathrm{hA}_{2 \mathrm{~A}} \mathrm{R}$ and improve the physicochemical properties of fluorescent ligands led to the discovery of MRS7416 (Fig. 3, Table 3), which is based on the antagonist SCH442416 [93]. As a fluorescent tracer, MRS7416 displayed low non-specific binding at $\mathrm{hA}_{2 \mathrm{~A}} \mathrm{R}$ in flow cytometry experiments. From molecular docking studies, the researchers suggested that the fluorescent AlexaFluor ${ }^{\circledR} 488$ moiety present in MRS7416 is binding to the hydrophilic extracellular loops of the receptor. This would make the probe essentially "bitopic," i.e., bridging two separate domains of the $h A_{2 A} R$. Very recently, the toolbox was expanded with a series of preladenant-based ligands equipped with a range of fluorophores [94]. These compounds showed $\mathrm{p} K_{D}$ values between 7.1 and 7.8 and were highly $\mathrm{A}_{2 \mathrm{~A}}$-selective with practically no binding to the other adenosine receptor subtypes.

\section{Fluorescent ligands for the adenosine $A_{2 B}$ receptor}

The first selective $A_{2 B}$ fluorescent ligand reported, PSB12105 (Fig. 3, Table 3), was synthesized by integrating a BODIPY moiety into the pharmacophore of 8-substituted xanthine derivatives [95]. Besides fluorescently labeling $\mathrm{CHO}$ cells expressing recombinant human $\mathrm{A}_{2 \mathrm{~B}} \mathrm{R}$, this ligand was used to establish an $\mathrm{A}_{2 \mathrm{~B}} \mathrm{R}$ binding assay on living cells in a flow cytometry setup. Barresi et al. reported on another series of (non-selective) fluorescent antagonists for labeling $A_{1}$ Rs and $A_{2 B} R s$ [96]. In one of the ligands, a fluorescent group, NBD (Fig. 3, Table 3), was linked to a triazinobenzimidazole scaffold. This fluorescent antagonist showed a clear labeling of bone marrow-derived mesenchymal stem cell membranes, which was largely prevented by pre-incubation with selective agonists for $A_{1} R$ and $A_{2 B} R$. These findings provide a sound basis for the design of novel fluorescent ligands to monitor the expression and localization of $\mathrm{A}_{2 \mathrm{~B}} \mathrm{R}$ in living cells. 


\section{Fluorescent ligands for the adenosine $A_{3}$ receptor}

The non-selective $A_{1} R / A_{3} R$ antagonist, CA200645, was employed as a tool compound to develop a robust competition binding assay to, e.g., screen for new chemical templates and fragments for $\mathrm{A}_{3} \mathrm{R}$ at a live cell high-content screening system $[87,88]$. Besides, CA200645 was also applied to study the $\mathrm{A}_{3} \mathrm{R}$ localization on intact human neutrophils. It appeared that $\mathrm{A}_{3} \mathrm{R}$ activation induces the formation of filipodia-like extensions and bacterial phagocytosis [103]. Modification of the linker component in CA200645 by the insertion of a dipeptide yielded two $\mathrm{A}_{3}$-selective fluorescent ligands, BODIPY 630/ 650-X-Tyr-Ser-XAC (Fig. 3, Table 3) and BODIPY FL-XTyr-Ser-XAC (Fig. 3, Table 3) [97]. Both ligands showed displaceable membrane binding with little non-specific binding in a fluorescent confocal microscopy setup. Additionally, these ligands were applied in a NanoBRET-based assay to study the kinetic aspects of ligand binding [98]. A similar strategy to incorporate a (three amino acid) peptide linker was applied to an existing non-selective adenosine-based fluorescent agonist, ABEA-X-BY630, yielding the highly potent fluorescent agonist BY630-X-( $D)$-Ala- $(D)$-Ala-Gly-ABEA at $A_{3} R$ [104]. This probe was used to visualize the internalization of YFP-tagged as well as -untagged receptors, and appeared to promote the formation of intracellular receptorarrestin-3 complexes. In addition, click chemistry serves as a versatile approach to simplify compound synthesis, as it provides the means for facile incorporation of fluorescent tags. CGS15943, a triazolo-quinazoline antagonist scaffold, was extended with an alkyne moiety to be click-conjugated with AlexaFluor ${ }^{\circledR} 488$, yielding a selective $\mathrm{A}_{3} \mathrm{R}$ fluorescent probe, MRS5449 (Fig. 3, Table 3) [99]. In flow cytometry, this molecular probe was used to quantify $\mathrm{hA}_{3} \mathrm{R}$ and to perform ligand screening in intact cells. The most recent addition to the $\mathrm{A}_{3} \mathrm{R}$ toolbox has been a series of pyrazolo[4,3-e]-1,2,4triazolo[1,5-c]pyrimidine derivatives equipped with fluorescein-based fluorophores FITC and AlexaFluor ${ }^{\circledR} 488$ [100]. The best compound from this series (MRS5763) exhibits a reasonable affinity of $32 \mathrm{nM}$ on the $h \mathrm{~A}_{3} \mathrm{R}$ and has some selectivity towards the $h \mathrm{~A}_{2 \mathrm{~A}} \mathrm{R}$.

\section{Covalent ligands}

Another class of molecular probes is formed by covalent ligands. The term covalent here refers to the ability of these compounds to bind the receptor irreversibly by forming a covalent bond to a specific amino acid residue located at or near the ligand binding site [105]. Depending on the type of covalent interaction induced, some different considerations are made concerning the design of these compounds. Generally, high affinity and selectivity for the target receptor will increase receptor occupancy and decrease non-specific or off-target binding, thus improving specific covalent labeling [106]. Two types of covalent ligands have been developed until now: electrophilic and photo-reactive ligands. Choosing the correct functional group (or warhead) that can react with the amino acid residues present in the binding site is essential for successful covalent probe design. Photo-reactive ligands possess a light-sensitive group, such as aryl azide, diazirine, or benzophenone, which is irradiated with light of a specific wavelength to yield highly reactive nitrene, carbene, or benzophenone-derived diradicals. These reactive species subsequently form a covalent bond with a neighboring amino acid residue through a variety of insertion reactions [107]. Photo-reactive ligands, occasionally combined with mass spectrometry, have been applied in GPCR research to determine the binding site of ligands and to identify the partner receptor for orphan ligands [108]. When combined with a radioactive label, photoaffinity probes emerge, which are used to study GPCR localization using autoradiography [109]. Electrophilic ligands on the other hand possess a reactive electrophile as a warhead, such as (iso)thiocyanate, sulfonyl fluoride, or a Michael acceptor like acrylamide. These electrophiles react with nucleophilic amino acid residues such as lysine, serine, and cysteine near the binding site of the ligand. When combined with in silico modeling and site-directed mutagenesis studies, these chemo-reactive ligands often enable characterization of the GPCR ligand binding site. Additionally, electrophilic covalent ligands have been applied to study receptor reserve, turnover, and subtype discrimination [110, 111]. Lastly, binding of a covalent ligand stabilizes the receptor into an active or inactive conformation, which in turn facilitates crystallization of the receptor-ligand complex. This aids in structural biology studies using X-ray diffraction or cryoEM, providing valuable insights into the structure and function of GPCRs [112]. A prime example of this is the case of the human adenosine $A_{1}$ receptor, which was recently cocrystallized with covalent antagonist DU172 [3]. There are numerous reported covalent ligands for adenosine receptors that have in some way contributed to the characterization of these receptors and their ligand binding sites. These ligands will be summarized below, and their applications will be discussed.

\section{Covalent ligands for the adenosine $A_{1}$ receptor}

Arguably, the first example of photoaffinity labeling of an adenosine receptor dates back to 1985 when $\mathrm{N}^{6}-2-(4-$ aminophenyl)ethyladenosine (APNEA), a non-selective adenosine-based agonist with high affinity for both $A_{1} R$ and $A_{3} R$, was coupled to the $A_{1} R$ [113]. In an attempt to characterize the $A_{1} R$ structure, radioiodinated ${ }^{125}$ I-APNEA (Fig. 4, Table 4) was incubated with $\mathrm{A}_{1} \mathrm{R}$ and reacted with crosslinking reagent $\mathrm{N}$ hydroxysuccinimidyl 6-(4-azido-2-nitrophenylamino)hexanoate (SANPAH) in situ. Subsequent UV irradiation resulted in a 38- 


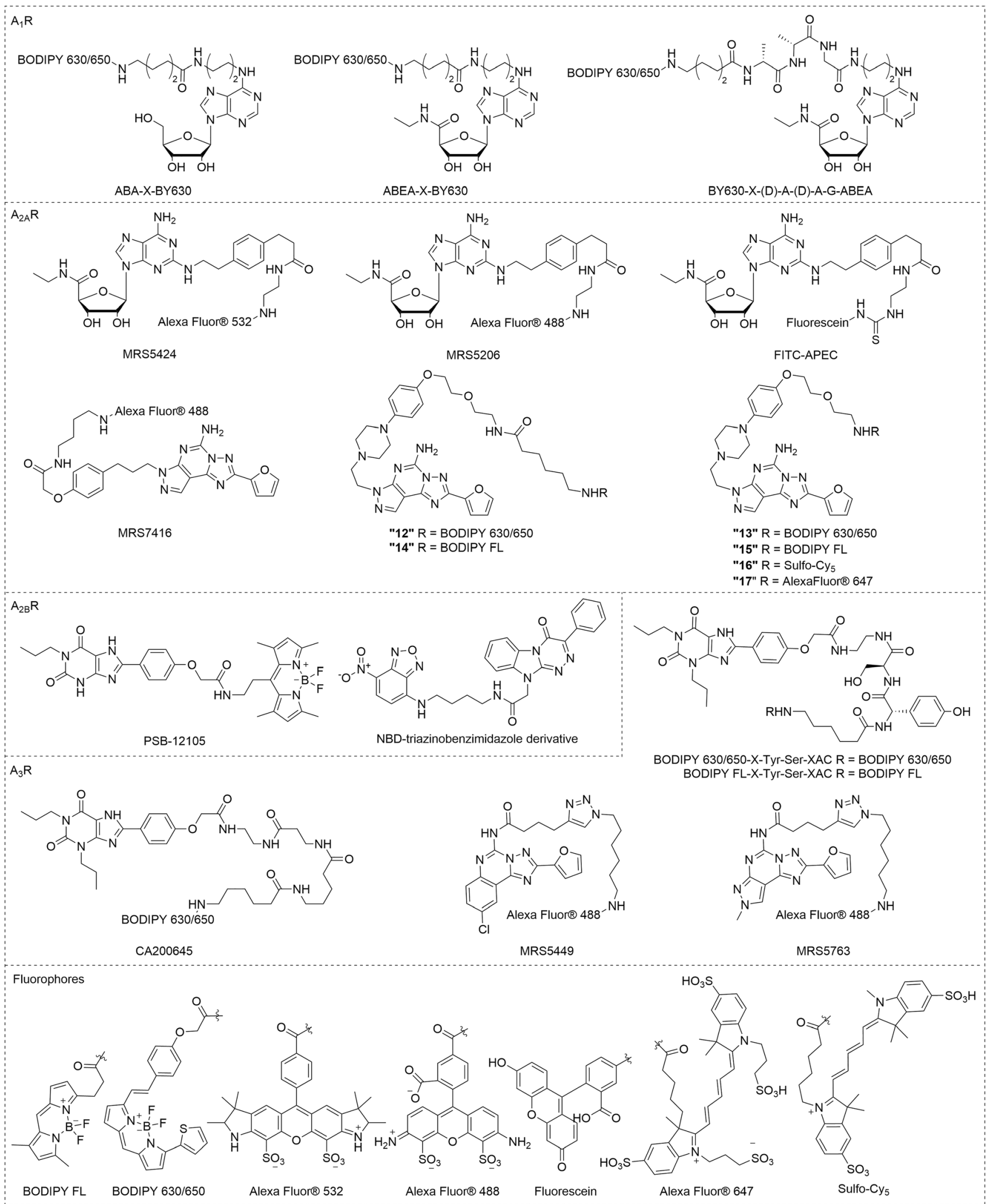

Fig. 3 Chemical structures of recent fluorescent tools for ARs

$\mathrm{kDa}$ protein being covalently labeled with the radioligand in rat cerebral cortex and adipocyte membranes. Since this process was completely blocked by co-incubating with a selective $\mathrm{A}_{1} \mathrm{R}$ agonist, this protein was designated as $A_{1} R$. Strictly speaking, this 
radioactive ligand is obviously not inherently photo-reactive and thus not a photoaffinity probe per se. Interestingly, in the same year, efforts to develop an inherently photo-reactive ligand based on the R-PIA scaffold, one of the most selective $\mathrm{A}_{1} \mathrm{R}$ agonists, were successful. A photoactivatable azido group was positioned at the purine core structure, generating the photolabile ligand $R$ AHPIA (Fig. 4, Table 4) [129]. It exhibited similar affinity $\left(K_{i}=\right.$ $1.5 \mathrm{nM})$ and efficacy $\left(\mathrm{EC}_{50}=35 \mathrm{nM}\right)$ as its parent compound, $R$ PIA, but after photoactivation, it showed irreversible inhibition of approximately $40 \%$ of the receptor binding sites. Such covalent labeling of $\mathrm{A}_{1} \mathrm{R}$ led to a concentration-dependent reduction of cellular cAMP levels, consistent with activation of $\mathrm{rA}_{1} \mathrm{R}$ and correlating with receptor occupancy [130]. Similar to the case of APNEA, when R-AHPIA was radioiodinated to yield ${ }^{125} \mathrm{I}$ AHPIA (Fig. 4, Table 4), SDS-PAGE analysis of rat brain membranes that were incubated with this covalent radioligand and UV-irradiated showed the appearance of a single protein band of $\sim 35 \mathrm{kDa}$ [129]. Interestingly, even though $R$-AHPIA is about 60 -fold selective for the $A_{1} R$, it is also a partial agonist at the $\mathrm{A}_{2 \mathrm{~A}} \mathrm{R}$, and pretreatment with $R$-AHPIA reduced the stimulatory effect of NECA, indicating persistent binding of the ligand and subsequent reduced activation by a full agonist [131]. In the search for covalent antagonists, 4-azidophenethyl xanthine derivative $\left[{ }^{125} \mathrm{I}\right] \mathrm{BW}-\mathrm{A} 947 \mathrm{U}$ (Fig. 4) was synthesized, and optimization (analogous to the development of selective $A_{1} R$ antagonist DPCPX) yielded the next photoactivatable antagonist, ${ }^{125}$ I-azido-BW-A844U (Fig. 4, Table 4) [114, 132, 133]. Both ligands are xanthine-based antagonists that have a light-sensitive aryl azide located on the xanthine 3-position. Photoaffinity labeling of partially purified receptor with ${ }^{125} \mathrm{I}$-azido-BW-A844U followed by chemical or enzymatic fragmentation experiments demonstrated that the covalently modified amino acids were located at transmembrane domain III of the $\mathrm{A}_{1} \mathrm{R}$. This approach provided clear insight into the amino acids surrounding the binding pocket of the $A_{1} R$ and thus aided in the development of three-dimensional models of the receptor.

Initial attempts in the development of chemo-reactive agonist ligands for the $A_{1} R$ were focused on functionalizing the adenosine scaffold with isothiocyanates or sulfonyl fluorides to serve as warheads $[115,134]$. In the first reported case, $p$ and $m$-DITC-ADAC (Fig. 4, Table 4), both adenosine derivatives with nanomolar affinity substituted on the $\mathrm{N}^{6}$-position with an isothiocyanate-bearing linker, were synthesized and tested on the $A_{1} R$ [135]. At nanomolar concentration, both ligands irreversibly occupied approximately half of the $A_{1} R$ binding sites. In a functional cAMP accumulation assay, both agonists elicited a sustained, antagonist-insensitive, $\mathrm{A}_{1} \mathrm{R}$-mediated response. Since the incorporation of a warhead via the

Table 3 Recent AR fluorescent ligands

\begin{tabular}{|c|c|c|c|c|c|c|c|}
\hline \multirow[t]{2}{*}{ Ligands } & & \multicolumn{4}{|l|}{$K_{i} / K_{D}^{\mathrm{a}}$} & \multirow[t]{2}{*}{ Functionality } & \multirow[t]{2}{*}{ Ref } \\
\hline & & $\mathrm{A}_{1}$ & $\mathrm{~A}_{2 \mathrm{~A}}$ & $\mathrm{~A}_{2 \mathrm{~B}}$ & $\mathrm{~A}_{3}$ & & \\
\hline \multirow[t]{4}{*}{$\mathrm{A}_{1}$} & CA200645 & 34 & N.D. & N.D. & 6.2 & Antagonist & {$[87,89]$} \\
\hline & ABA-X-BY630 & 589 & N.D. & N.D. & N.D. & Agonist & {$[90]$} \\
\hline & ABEA-X-BY630 & 1023 & N.D. & N.D. & N.D. & Agonist & {$[90]$} \\
\hline & BY630-X-AAG-ABEA & 676 & N.D. & N.D. & N.D. & Agonist & {$[90]$} \\
\hline \multirow[t]{8}{*}{$\mathrm{A}_{2 \mathrm{~A}}$} & FITC-APEC & N.D. & 57 (bovine) & N.D. & N.D. & Agonist & {$[91,92]$} \\
\hline & MRS7416 & 1680 & 30 & N.D. & $32 \%(10 \mu \mathrm{M})$ & Antagonist & [93] \\
\hline & “12" & $0^{\mathrm{b}}$ & 41 & $0^{\mathrm{b}}$ & $0^{\mathrm{b}}$ & Antagonist & [94] \\
\hline & "13" & $0^{\mathrm{b}}$ & 41 & $0^{\mathrm{b}}$ & $0^{\mathrm{b}}$ & Antagonist & [94] \\
\hline & "14" & $0^{\mathrm{b}}$ & 17 & $0^{\mathrm{b}}$ & $0^{\mathrm{b}}$ & Antagonist & {$[94]$} \\
\hline & "15" & $0^{\mathrm{b}}$ & 22 & $0^{\mathrm{b}}$ & $0^{\mathrm{b}}$ & Antagonist & [94] \\
\hline & "16" & $0^{\mathrm{b}}$ & 83 & $0^{\mathrm{b}}$ & $0^{\mathrm{b}}$ & Antagonist & {$[94]$} \\
\hline & "17" & $0^{\mathrm{b}}$ & 60 & $0^{\mathrm{b}}$ & $0^{\mathrm{b}}$ & Antagonist & [94] \\
\hline \multirow[t]{2}{*}{$\mathrm{A}_{2 \mathrm{~B}}$} & PSB-12105 & $\geq 10,000$ & $>10,000$ & 1.8 & $>10,000$ & Antagonist & {$[95]$} \\
\hline & NBD-derivative & 1380 & $>10,000$ & $20 \%^{\mathrm{c}}(10 \mu \mathrm{M})$ & $>10,000$ & Antagonist & {$[96]$} \\
\hline \multirow[t]{4}{*}{$\mathrm{A}_{3}$} & BODIPY 630/650-X-Tyr-Ser-XAC & 24 & N.D. & N.D. & 0.76 & Antagonist & {$[97,98]$} \\
\hline & BODIPY FL-X-Tyr-Ser-XAC & 316 & N.D. & N.D. & 11 & Antagonist & {$[97,98]$} \\
\hline & MRS5449 & 87 & 73 & N.D. & 6.4 & Antagonist & [99] \\
\hline & MRS5763 & N.D. & 90 & N.D. & 32 & Antagonist & {$[100]$} \\
\hline
\end{tabular}

N.D. not determined

${ }^{\text {a }} K_{i} / K_{D}$ values for compounds for the indicated human adenosine receptors

${ }^{\mathrm{b}}$ Specific BRET ratio on respective (NanoLuc-labeled) adenosine receptors

${ }^{\mathrm{c}} \%$ of cAMP production induced by $100 \mathrm{nM}$ of NECA in $\mathrm{CHO}$ cells expressing human $\mathrm{A}_{2 \mathrm{~B}} \mathrm{R}$ at 10 -nM concentration compound 
$\mathrm{N}^{6}$-position of the adenosine scaffold was well tolerated and showed no negative effect on the ligands' affinities, a series of adenosine derivatives bearing diverse linker types and warheads were synthesized and examined. Two promising compounds, isothiocyanate $15 \mathrm{~b}$ and sulfonyl fluoride $15 \mathrm{~d}$ (Fig. 4, Table 4), were validated as irreversible agonists promoting persistent $\mathrm{A}_{1} \mathrm{R}$-mediated guanine nucleotide exchange activity in a manner resistant to both agonist and antagonist addition [134]. Furthermore, these two ligands demonstrated their capacity to thermo-stabilize purified, detergent-solubilized $A_{1} R$ in a ThermoFluor assay to a significantly higher degree than the high-affinity agonist NECA could. These thermostabilized receptors with covalently bound ligands allowed purification of the receptor in a monodisperse state, which greatly facilitated structure determination by X-ray crystallography [134]. Very recently, our group reported a capadenoson derivative, which was equipped with a fluorosulfonyl warhead to give LUF7746, a non-ribose (dicyanopyridine-based) partial agonist for the $A_{1} R$ [116]. This compound was shown to selectively bind the $A_{1} R$ in a time-dependent manner with an apparent affinity (at $4 \mathrm{~h}$ pre-incubation) in the low-nanomolar range. Additionally, LUF7746 was compared to LUF7747, a non-reactive methylsulfonyl control compound, which showed no time-dependent binding. Interestingly, whereas both compounds showed an intrinsic activity with $E_{\max }$ around $60 \%$, which was also demonstrated in a label-free whole cell assay, only the effect of LUF7747 could be diminished by the addition of antagonist DPCPX. The ability of LUF7746 to persistently activate the receptor was largely abolished by performing site-directed mutagenesis

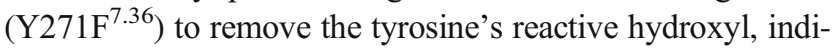
cating the importance of this conserved amino acid in the covalent interaction. With respect to chemo-reactive antagonists, two approaches have been explored, both starting from the xanthine scaffold. The first class comprises the 8substituted 1,3-dipropylxanthines [136]. One such compound is $m$-DITC-XAC (Fig. 4, Table 4), an isothiocyanate derivative of the relatively non-selective AR antagonist XAC. It was found to be a potent $\mathrm{A}_{1} \mathrm{R}$ antagonist in rat brain $\left(K_{i}=2.4 \mathrm{nM}\right)$ and was used to study the receptor reserve in guinea pig atrioventricular nodes [137]. In the second approach, the electrophilic fluorosulfonyl group was placed on the 3-position of the xanthine core, as was done in covalent tool FSCPX (Fig. 4, Table 4) [138]. This compound had a good affinity for the $\mathrm{A}_{1} \mathrm{R}\left(\mathrm{IC}_{50}=10 \mathrm{nM}\right)$, and treatment with 10 - or $50-\mathrm{nM}$ FSCPX led to reductions in the available $\mathrm{A}_{1} \mathrm{R}$ binding sites of $60 \%$ and $74 \%$, respectively. In a follow-up study, it was demonstrated that FSCPX irreversibly antagonized cardiac $\mathrm{A}_{1} \mathrm{R}$-mediated responses. Subsequently, it was shown that FSCPX was unable to significantly decrease the maximal direct inotropic response to four $\mathrm{A}_{1} \mathrm{R}$ full agonists (NECA, $\mathrm{CPA}, \mathrm{CHA}$, and adenosine) in guinea pig atria, which demonstrated a considerable $A_{1} R$ reserve for direct negative inotropy [139]. In in vivo experiments, FSCPX was used successfully as a "receptor knock-down" tool when IV infusion of FSCPX in conscious rats attenuated CPA-mediated bradycardia [140]. As the ester bond present near the warhead of FSCPX is prone to hydrolysis, a follow-up structural modification was performed with a focus on linker types $[117,141]$. This resulted in a closely related analog with improved stability, DU172 (Fig. 4, Table 4). The affinity of DU172 $\left(\mathrm{IC}_{50}=\right.$ $25 \mathrm{nM}$ ) was in line with that of FSCPX, and pretreatment of $\mathrm{DDT}_{1}$ MF2 cells with DU172 resulted in a concentrationdependent decrease in the $A_{1} R$ binding sites, indicating that it behaved as an irreversible ligand indeed. This covalent ligand-receptor interaction has been the basis for the structure elucidation of $\mathrm{A}_{1} \mathrm{R}$ due to improved receptor stability [3].

\section{Covalent ligands for the adenosine $A_{2 A}$ receptor}

For the $\mathrm{A}_{2 \mathrm{~A}} \mathrm{R}$, initial characterization of the receptor was aided by a radioiodinated analog of APEC, a prototypical ribosebased selective $A_{2 A} R$ agonist. Similar to the initial $A_{1} R$ studies, ${ }^{125}$ I-PAPA-APEC (Fig. 5, Table 4) was cross-linked to the $\mathrm{A}_{2 \mathrm{~A}} \mathrm{R}$ in bovine striatal membranes using SANPAH and was shown to covalently label a $45-\mathrm{kDa}$ protein $[121,142]$. Both NECA and R-PIA were able to prevent the covalent labeling of the $45-\mathrm{kDa}$ protein by ${ }^{125}$ I-PAPA-APEC, providing evidence that this protein is the $A_{2 A} R$ indeed. Subsequently, the photoactivatable azido analog ${ }^{125}$ I-azido-PAPA-APEC (Fig. 5 , Table 4) was developed and was used to directly label the same $45-\mathrm{kDa}$ protein in bovine striatal membranes with 3-fold greater efficiency of photo-incorporation [118]. A further characterization of the binding domain was performed by Piersen et al., who performed photoaffinity labeling of the canine $\mathrm{A}_{2 \mathrm{~A}} \mathrm{R}$ overexpressed in COS M6 cells with ${ }^{125}$ I-azido-PAPA-APEC and tracked the cross-linked transmembrane domain V [143]. However, no individual amino acid residues responsible for the covalent interaction were identified. These studies were later repeated with a novel adenosine-based radioligand $\left[{ }^{125} \mathrm{I}\right] \mathrm{I}-\mathrm{APE}$, which showed less hydrophobic interactions than ${ }^{125}$ I-PAPA-APEC and had higher specific radioactivity than $\left[{ }^{3} \mathrm{H}\right] \mathrm{CGS} 21680$ [119]. Its azido analog, $\left[{ }^{125} \mathrm{I}\right]$ AzPE (Fig. 5, Table 4), showed saturable, high-affinity binding in rabbit striatal membranes $\left(K_{D}=1.7 \mathrm{nM}\right)$, and photolabeling identified a protein of $45 \mathrm{kDa}$ that displayed the appropriate pharmacology of the $\mathrm{A}_{2 \mathrm{~A}} \mathrm{R}$. More recently, photoaffinity labeling has been combined with mass spectrometry analysis to map detailed ligand-receptor binding sites. Muranaka et al. started from the not-so- $\mathrm{A}_{2 \mathrm{~A}} \mathrm{R}$-selective SCH58261 scaffold [144] and incorporated the trifluoromethyl diazirine group to yield photoaffinity ligand 9 (Fig. 5, Table 4) [120]. When purified $\mathrm{hA}_{2 \mathrm{~A}} \mathrm{R}$ was photolabeled with this ligand and subjected to protease digestion, cross-link positions were identified with LC-MS/MS. The most likely amino acid candidate for this ligand was 
Y $271^{7.36}$ in transmembrane domain VII. This is the first reported case in which the cross-linked amino acid was elucidated by mass spectrometry, which demonstrates the power of combining mass spectrometry-based proteomics and covalent labeling in the elucidation and characterization of GPCR ligand binding sites.

Analogous to the photo-reactive ligands, APEC also served as a parent ligand for the initial design of chemo-reactive ligands for $\mathrm{A}_{2 \mathrm{~A}} \mathrm{R}$. One exemplary compound is $p$-DITCAPEC (Fig. 5, Table 4), which has a reactive 4isothiocyanatophenyl residue attached to the $\mathrm{C}-2$ substituent of the purine ring [121]. It had good affinity $\left(K_{i}=7.1 \mathrm{nM}\right.$ at bovine $\left.\mathrm{A}_{2 \mathrm{~A}} \mathrm{R}\right)$ [121] and, at a concentration of $100 \mathrm{nM}$, irreversibly blocked $77 \%$ of $\left[{ }^{3} \mathrm{H}\right] \mathrm{CGS} 21680$ binding in rabbit striatal membranes [145]. In isolated, perfused guinea pig hearts, treatment with $p$-DITC-APEC caused a prolonged, persistent, and concentration-dependent coronary vasodilatation, which is evidence of an irreversible activation of $A_{2 A} R$ [146]. More recently, an APEC analog bearing an active 2nitrophenyl ester was synthesized (MRS5854, Fig. 5, Table 4). This ligand was designed to bind to the receptor irreversibly and subsequently transfer its terminal acyl group to a nucleophilic amino acid residue on extracellular loop 2 (ECL2) of the $\mathrm{A}_{2 \mathrm{~A}} \mathrm{R}$ [122]. This acyl transfer would prevent the ECL2-lysine-mediated recognition of ligands, effectively blocking the receptor. Pre-incubation of $\mathrm{hA}_{2 \mathrm{~A}} \mathrm{R}$ with
MRS5854 followed by extensive washing indeed showed near-complete inhibition of radioligand binding. When ECL2-lysine K153 was mutated to an alanine residue, a partial restoration of $B_{\max }$ was observed after treatment with MRS5854, confirming that K153 is the anchor point for the covalent interaction. Interestingly, the $K_{D}$ for the radioligand used $\left(\left[{ }^{3} \mathrm{H}\right] \mathrm{ZM} 241385\right)$ was not significantly influenced by this mutation, indicating that the targeted lysine residue is not important for ligand binding and that acyl transfer seems to prevent binding by blocking entry to the binding pocket instead of preventing the recognition of ligands. In parallel, the active acyl was replaced by an azido-pentanoate group to generate MRS5854-azide. Although this ligand showed diminished affinity towards the $\mathrm{A}_{2 \mathrm{~A}} \mathrm{R}$, it nevertheless caused a slight reduction in $B_{\max }$, suggesting that at least part of the receptors was covalently labeled with the azido-pentanoate. This azido group would theoretically allow for click-ligation to functionalized alkynes; however, applications have not yet been reported.

Three approaches have been taken to develop electrophilic covalent probes for the $\mathrm{A}_{2 \mathrm{~A}} \mathrm{R}$. The first example is ISC (Fig. 5, Table 4), an isothiocyanate-functionalized xanthine-based antagonist for $\mathrm{A}_{2 \mathrm{~A}} \mathrm{R}$, which irreversibly binds to $80 \%$ of $\mathrm{rA}_{2 \mathrm{~A}} \mathrm{R}$ at $20 \mu \mathrm{M}$ [123]. A second approach yielded FSPTP (Fig. 5, Table 4), the para-fluorosulfonyl derivative of SCH58261, which was used to investigate the level of $A_{2 A} R$ reserve<smiles>CCCn1c(=O)c2[nH]c(C3CCCC3)nc2n(CCc2ccc(N)c([18OH])c2)c1=O</smiles>

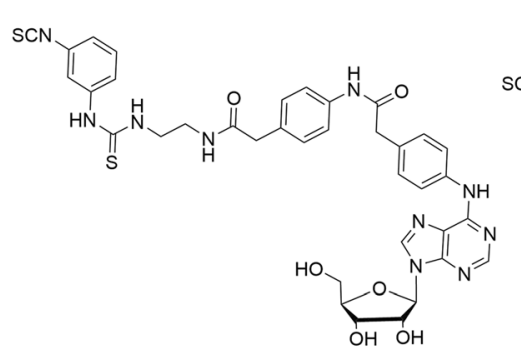

m-DITC-ADAC

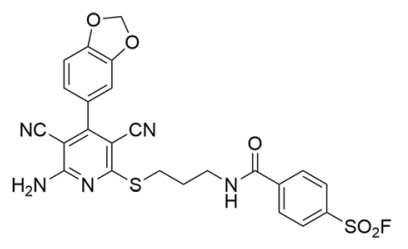

LUF7746

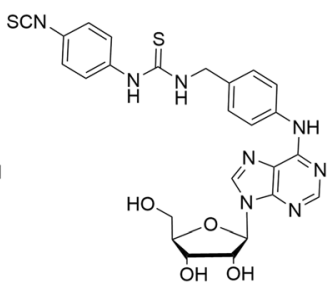

"15b"

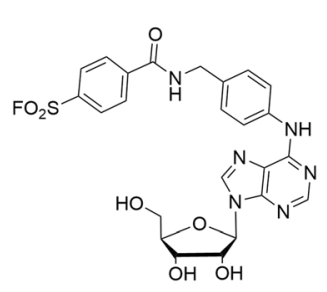

"15d"

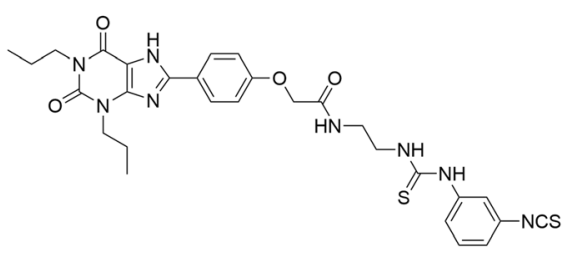

m-DTIC-XAC
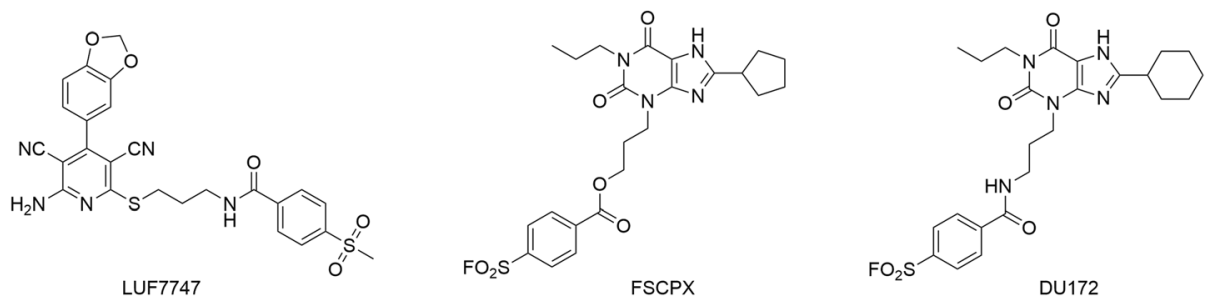

Fig. 4 Chemical structures of covalent ligands for $A_{1} R$. LUF7747 is a reversible control ligand for LUF7746 
[147]. More recently, our research group used the molecular structure of the antagonist ZM241385 as a starting point for the design of a third electrophilic covalent ligand. This endeavor yielded LUF7445 (Fig. 5, Table 4), a potent fluorosulfonyl-equipped antagonist with an apparent affinity for the $\mathrm{hA}_{2 \mathrm{~A}} \mathrm{R}$ in the nanomolar range $\left(\mathrm{p} K_{i}=8.99\right)$ [124]. Aided by site-directed mutagenesis studies, it was shown that LUF7445 binds to K153 ${ }^{\mathrm{ECL} 2}$, the same residue that was also involved in the acyl transfer of covalent agonist MRS5854. After optimization of the chemical structure, the most potent ligand was retained for further structural modification and was equipped with an alkyne click handle (adjacent to the warhead), resulting in the bifunctional probe LUF7487 (Fig. 5, Table 4) [6]. This affinity-based probe made it possible to visualize the receptor on SDS-PAGE via click-ligation with a sulfonated Cy-3 fluorophore. The $\mathrm{hA}_{2 \mathrm{~A}} \mathrm{R}$ was successfully labeled in cell membranes, making LUF7487 a promising tool compound that sets the stage for the further development of probes to study GPCRs. The development of affinity-based probes may open the door for the identification and target validation of GPCRs in a more native environment.

\section{Covalent ligands for the adenosine $A_{3}$ receptor}

While there are no photo-reactive or chemo-reactive ligands available for the $A_{2 B} R$, the case for the $A_{3} R$ is also still rather minimal. No photo-reactive ligands and only four "classes" of chemo-reactive ligands are available for the $\mathrm{A}_{3} \mathrm{R}$. MRS1163 (Fig. 6, Table 4), the only irreversibly binding agonist for the $A_{3} R$, was derived from the selective $A_{3} R$ agonist IB-MECA [125]. It features a chemo-reactive isothiocyanate moiety, which replaced the iodine substituent on IB-MECA, and showed an apparent $K_{i}$ value in the low-nanomolar range $(10 \mathrm{nM})$, which is comparable to IB-MECA. Treatment of $\mathrm{rA}_{3} \mathrm{R}$ with $100 \mathrm{nM}$ of MRS1163 led to a $41 \%$ loss in the available receptor binding sites, and its irreversible nature was demonstrated by the lack of recovery of $\mathrm{A}_{3} \mathrm{R}$ binding sites after extensive washing. Using a "functionalized congener

Table 4 Covalent ligands for adenosine receptors

\begin{tabular}{|c|c|c|c|c|c|c|c|}
\hline \multicolumn{2}{|c|}{ Ligands } & \multicolumn{4}{|c|}{ Apparent $\mathrm{IC}_{50} / K_{i} / K_{D}(\mathrm{nM})^{\mathrm{a}}$} & \multirow[t]{2}{*}{ Functionality } & \multirow[t]{2}{*}{ Ref } \\
\hline & & $\mathrm{A}_{1}$ & $\mathrm{~A}_{2 \mathrm{~A}}$ & $\mathrm{~A}_{2 \mathrm{~B}}$ & $\mathrm{~A}_{3}$ & & \\
\hline \multirow[t]{10}{*}{$\mathrm{A}_{1}$} & ${ }^{125}$ I-APNEA & $2.0(\mathrm{r})$ & N.D. & N.D. & N.D. & Agonist & [113] \\
\hline & $R$-AHPIA & $1.6(r)$ & N.D. & N.D. & N.D. & Agonist & [113] \\
\hline & ${ }^{125}$ I-AHPIA & $2.0(\mathrm{r})$ & N.D. & N.D. & N.D. & Agonist & [113] \\
\hline & ${ }^{125}$ I-azido-BW-A844U & $0.14(\mathrm{~b})$ & N.D. & N.D. & N.D. & Antagonist & [114] \\
\hline & $p$-DITC-ADAC & $0.47(\mathrm{r})$ & $191(r)$ & N.D. & N.D. & Agonist & [115] \\
\hline & $m$-DITC-ADAC & $0.87(\mathrm{r})$ & $176(r)$ & N.D. & N.D. & Agonist & [115] \\
\hline & LUF7746 & 4.0 & $26 \%(1 \mu \mathrm{M})$ & $26 \%(1 \mu \mathrm{M})$ & $25 \%(1 \mu \mathrm{M})$ & Partial agonist & [116] \\
\hline & $m$-DITC-XAC & $2.4(r)$ & $343(r)$ & N.D. & N.D. & Antagonist & [115] \\
\hline & FSCPX & 12 & 1200 & N.D. & N.D. & Antagonist & [117] \\
\hline & DU172 & 21 & 2.8 & N.D. & N.D. & Antagonist & [117] \\
\hline \multirow[t]{9}{*}{$\mathrm{A}_{2 \mathrm{~A}}$} & ${ }^{125}$ I-azido-PAPA-APEC & N.D. & 1.2 & N.D. & N.D. & Agonist & [118] \\
\hline & {$\left[{ }^{125} \mathrm{I}\right] \mathrm{AzPE}$} & N.D. & 1.7 & N.D. & N.D. & Agonist & [119] \\
\hline & 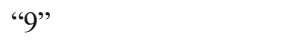 & N.D. & 40 & N.D. & N.D. & Agonist & [120] \\
\hline & $p$-DITC-APEC & $276(r)$ & $35(\mathrm{r})$ & N.D. & N.D. & Agonist & [121] \\
\hline & MRS5854 & 500 & 23 & N.D. & 207 & Agonist & [122] \\
\hline & MRS5854-azide & $30 \%(10 \mu \mathrm{M})$ & 4360 & N.D. & 1810 & Agonist & [122] \\
\hline & ISC & 20,300 & 111 & N.D. & & Antagonist & [123] \\
\hline & LUF7445 & 372 & 1.0 & $0 \%(1 \mu \mathrm{M})$ & 49 & Antagonist & [124] \\
\hline & LUF7487 & 19 & 1.5 & N.D. & 60 & Antagonist & [6] \\
\hline \multirow[t]{4}{*}{$\mathrm{A}_{3}$} & MRS1163 & $145(\mathrm{r})$ & $272(r)$ & N.D. & $10.0(\mathrm{r})$ & Agonist & [125] \\
\hline & $\mathrm{SO}_{2} \mathrm{~F}-\mathrm{MRS} 1191$ & $41 \%(100 \mu \mathrm{M}, \mathrm{r})$ & $20 \%(100 \mu \mathrm{M}, \mathrm{r})$ & N.D. & 2.4 & Antagonist & [126] \\
\hline & $\mathrm{SO}_{2} \mathrm{~F}-\mathrm{MRE}-3008-\mathrm{F} 20$ & $<5 \%(100 \mathrm{nM})$ & 50 & N.D. & $79 \%(100 \mathrm{nM})$ & Antagonist & [127] \\
\hline & LUF7602 & 794 & 1300 & $0 \%(10 \mu \mathrm{M})$ & 10 & Antagonist & [128] \\
\hline
\end{tabular}

N.D. not determined

${ }^{\mathrm{a}}$ The data are apparent affinities (nM) for the human adenosine receptors or $\%$ displacement at the concentration in brackets unless indicated otherwise ( $\mathrm{r}$ $=$ rat, $\mathrm{b}=$ bovine) 
approach," the Jacobson group developed an electrophilic antagonist for the $\mathrm{A}_{3} \mathrm{R}$ based on the 1,4-dihydropyridine template, a selective $\mathrm{A}_{3} \mathrm{R}$ scaffold. A fluorosulfonyl-substituted phenyl group was installed on MRS1191, thereby generating the functionalized congener $\mathrm{SO}_{2} \mathrm{~F}-\mathrm{MRS} 1191$ (Fig. 6, Table 4) [126]. It was reported to possess improved affinity $(2.4 \mathrm{nM})$ over the corresponding sulfonamide compound (292 nM). When $100 \mathrm{nM}$ of $\mathrm{SO}_{2} \mathrm{~F}-\mathrm{MRS} 1191$ was incubated with hA 3 R-transfected HEK-293 cell membranes, approximately $56 \%$ of the $\mathrm{hA}_{3} \mathrm{R}$ binding sites were irreversibly occupied. A second covalent antagonist was generated based on MRE3008-F20, a highly potent and selective $A_{3} R$ antagonist [127]. By replacing the methoxy group in MRE-3008-F20 with a sulfonyl fluoride moiety, an irreversibly binding derivative, $\mathrm{SO}_{2}$ F-MRE-3008-F20 (Fig. 6, Table 4), was synthesized. At a concentration of $100 \mathrm{nM}, \mathrm{SO}_{2} \mathrm{~F}-\mathrm{MRE}-3008-\mathrm{F} 20$ inhibited binding of the radioligand $\left[{ }^{125} \mathrm{I}\right] \mathrm{I}-\mathrm{AB}-\mathrm{MECA}$ by $79 \%$. By docking the ligand in a homology model of the $\mathrm{A}_{3} \mathrm{R}$, it was speculated that two amino acids, Cys251 or Ser247, are the most probable binding partners for covalent interaction. Recently, our group also designed covalent antagonists for the $\mathrm{hA}_{3} \mathrm{R}$ [128]. A series of tricyclic xanthinederived ligands bearing a fluorosulfonyl warhead and varying linkers was synthesized. The most potent ligand, LUF7602
(Fig. 6, Table 4), had high affinity for the $\mathrm{hA}_{3} \mathrm{R}\left(K_{i}=\right.$ $10 \mathrm{nM}$ ). Additionally, a non-reactive methylsulfonyl derivative LUF7714 was developed as a reversible control compound. A series of assays, comprising of time-dependent affinity determination, washout experiments, and $\left[{ }^{35} \mathrm{~S}\right] \mathrm{GTP} \gamma \mathrm{S}$ binding assays, then validated LUF7602 as a covalent antagonist. Based on homology docking, tyrosine Y265 7.36 was identified as potential covalent anchor, and when this residue was mutated to phenylalanine, the mutant receptor displayed a significant decrease in affinity for LUF7602 $\left(\mathrm{IC}_{50}=16 \mathrm{nM}\right.$ for $\mathrm{hA}$ R-WT, $\mathrm{IC}_{50}=1000 \mathrm{nM}$ for $\mathrm{hA}_{3} \mathrm{R}-\mathrm{Y} 265^{7.36} \mathrm{~F}$ ), while the affinity of LUF7714 $\left(\mathrm{IC}_{50}=1259 \mathrm{nM}\right.$ for $\mathrm{hA}_{3} \mathrm{R}-\mathrm{WT}$, $\mathrm{IC}_{50}=1000 \mathrm{nM}$ for $\mathrm{hA}$ R-Y $265^{7.36} \mathrm{~F}$ ) was unaltered. It is worth mentioning that this particular tyrosine residue is conserved among adenosine receptors and is also the anchor point of DU172 and LUF7746, the aforementioned covalent antagonist and partial agonist for the $\mathrm{hA} \mathrm{A}_{1} \mathrm{R}$ [117]. Hence, this tyrosine residue potentially represents a universal anchor point for covalent probes designed for adenosine receptors. In general, covalent probes, supported by molecular modeling and sitedirected mutagenesis, can serve as powerful tools to characterize the spatial orientation and topography of ligand-receptor binding sites.
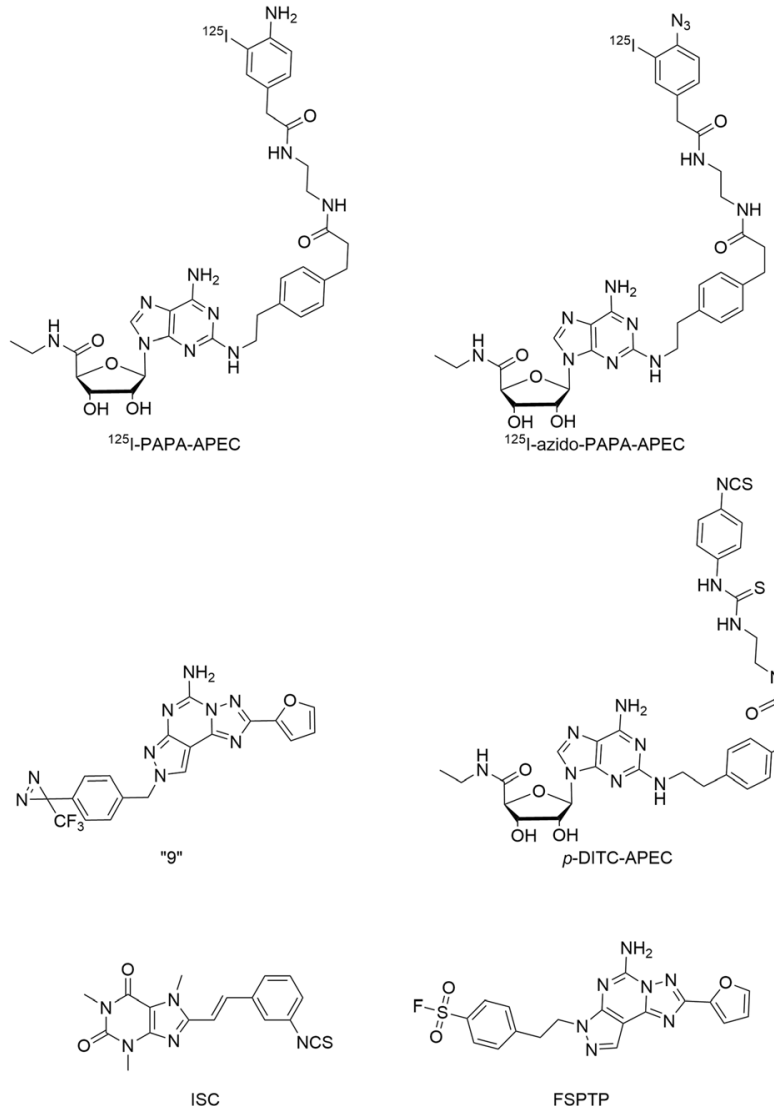

FSPTP

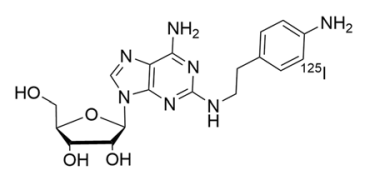

$\left[^{125}\right]$ ]-APE
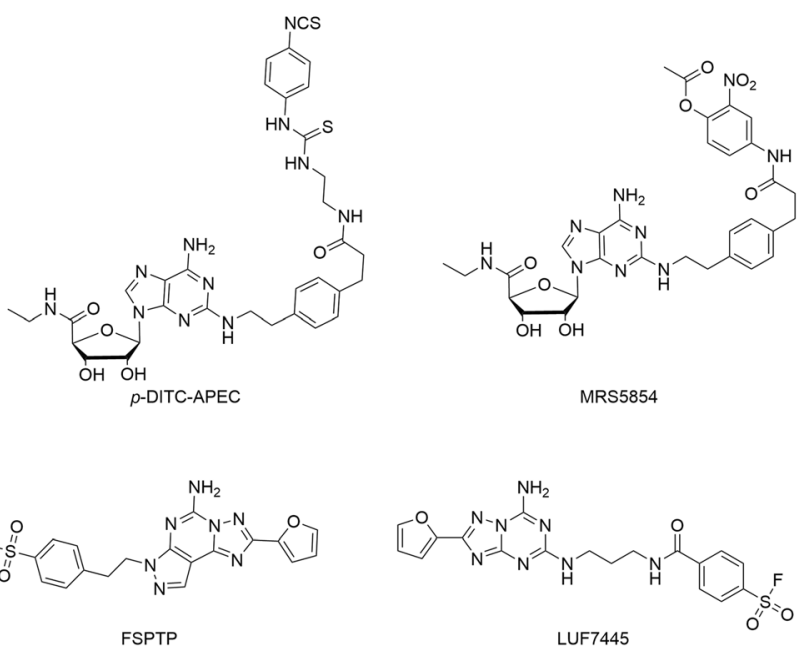

MRS5854<smiles>Nc1ccc(CCNc2nc(N)c3ncn(C4OC(O)C(O)C4O)c3n2)cc1</smiles>

$\left.\left[{ }^{125}\right]\right] \mathrm{AzPE}$
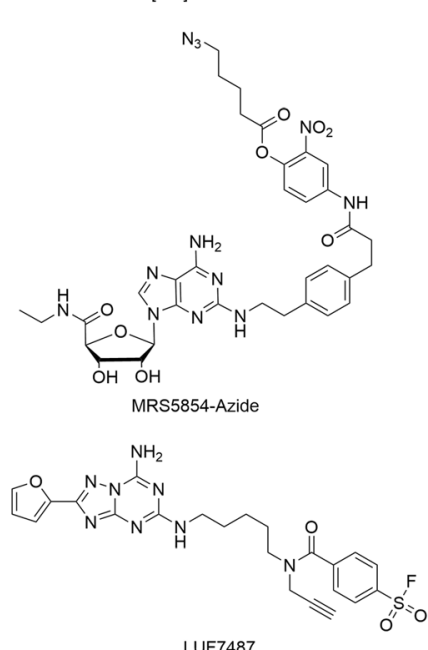

Fig. 5 Chemical structures of covalent ligands for $A_{2 A} R$ 
<smiles></smiles>

MRS1163<smiles>CCOC(=O)C1=C(C)NC(c2ccccc2)=C(C(=O)OCc2ccc(S(=O)(=O)F)cc2)C1C#Cc1ccccc1</smiles>

$\mathrm{SO}_{2}$ F-MRS1191<smiles>CCCn1cc2c(nc(NC(=O)Nc3ccc(S(=O)(=O)F)cc3)n3nc(-c4ccco4)nc23)n1</smiles>

$\mathrm{SO}_{2} \mathrm{~F}-\mathrm{MRE}-3008-\mathrm{F} 20$<smiles>CCCn1c(=O)c(=O)n(CCCNC(=O)c2ccc(S(C)(=O)=O)cc2)c2nc3cc(OC)ccn3c2c1=O</smiles>

LUF7602

LUF7714

Fig. 6 Chemical structures of covalent ligands for $A_{3} R$. LUF7714 is a reversible control ligand for LUF7602

\section{Concluding remarks}

Molecular probes, including radioligands and fluorescent and covalent ligands, are important tool compounds that facilitate the biochemical and structural investigation of GPCRs. As shown in this review, these probes provide information about the nature of adenosine receptors, next to a deeper understanding of receptor regulation and the pathological and physiological roles of this GPCR subfamily. In particular, when combined with other techniques such as receptor mutagenesis, X-ray crystallography, and homology modeling, these tools provide a powerful platform for molecular receptor pharmacology.

Radioligands are the most developed tools for GPCRs. An established standard radioligand binding assay provides crucial and reliable measurements of GPCRs interacting with their synthetic ligands as well as newly developed probes.
Binding of an agonist radioligand may reveal different apparent affinity states depending on the receptor states (i.e., $\mathrm{G}$ protein-coupled and G protein-uncoupled) or cell-dependent effector coupling; agonist binding often labels the $\mathrm{G}$ proteincoupled ("active") state of the receptor only. Thus, antagonist radioligands are generally considered more acceptable in receptor classification than agonists. Among the adenosine receptors, there is still an urgent need for the development of antagonist radioligands for the $\mathrm{A}_{2 \mathrm{~B}} \mathrm{R}$ and $\mathrm{A}_{3} \mathrm{R}$ with high affinity ( $K_{D}$ values of $1 \mathrm{nM}$ or less), low non-specific binding, and better selectivity. For in vivo assays, the development of PET ligands targeting $\mathrm{A}_{2 \mathrm{~B}} \mathrm{R}$ and $\mathrm{A}_{3} \mathrm{R}$ has still been limited to receptor occupancy studies, biodistribution, or pharmacokinetic characterization, while PET ligands for $A_{1} R$ and $A_{2 A} R$ have blossomed in clinical studies, particularly for neurological disorders. Studies on $\mathrm{A}_{2 \mathrm{~B}} \mathrm{R}$ and $\mathrm{A}_{3} \mathrm{R}$ are generally considered to be hampered by the low expression level of these

Table 5 Major pros and cons of radioligands versus fluorescent ligands

\begin{tabular}{|c|c|c|c|}
\hline \multicolumn{2}{|l|}{ Radioligands } & \multicolumn{2}{|l|}{ Fluorescent ligands } \\
\hline Pro & Con & Pro & Con \\
\hline Established standard assays & Radiation concerns & No radiation/safety issues, easy handling & Target often engineered \\
\hline Highly sensitive & Limited shelf life & Shelf stable & Non-specific binding, sensitivity \\
\hline In vivo use (PET ligands) & Limited "real-time" readout & "Real-time" measurements & Limited in vivo applicability \\
\hline Commercial availability & Safety issues, waste handling & Application in microscopy setup & Tag size \\
\hline
\end{tabular}


receptors in endogenous tissue, insufficient affinity of the tool compound, and unclear mechanisms involved in receptor function. It is anticipated that continued efforts to develop high-affinity and selective PET tracers for adenosine receptors will further our understanding of the role these receptors have in disease conditions.

Concerns about radiation safety and shelf life have fueled the continuing interest in small-molecule fluorescent tools. Recent examples summarized in this review demonstrate that fluorescent probes represent an alternative approach to investigate AR characteristics. However, their use is still suboptimal due to the often high level of non-specific membrane binding brought by the hydrophobic pharmacophore and fluorophore. Hence, researchers should pay more attention to designing probes with favorable physicochemical properties. Besides, the in vivo applications of such tools are still hampered, partly due to their short excitation wavelengths and low tissue penetration [148]. Future development of synthetic ligands with a focus on near-infrared (NIR) fluorophores might be advantageous, especially since such wavelengths are not harmful to cells and have a relatively low absorption. NIR probes have already been employed to study the cannabinoid $\mathrm{CB}_{2}$ and $\alpha_{1}$-adrenergic receptors [149, 150]. Depending on the intended goal and applicability domain, careful consideration of the pros and cons of fluorescent or radiolabeled compounds (Table 5) is essential.

Compared to radioligand and fluorescent probes, covalent ligands do not possess any detectable functionality for direct quantification or visualization of receptors. However, when combined with site-direct mutagenesis, mass spectrometry, and peptide sequencing, they constitute a powerful approach compared to classic reversible ligands to study adenosine receptor subtype and structure, map ligand binding sites, investigate the physiological and pathological roles of receptors, and determine the correlation between receptor occupancy and response (Table 6). The emergence of the activity-based protein profiling technique inspired researchers to equip probes with click handles to yield bifunctional probes that can be used to visualize receptors for target validation. In this strategy, a probe binds the receptor with less perturbation compared to relatively large tags linked to ligand scaffolds beforehand, which bridges the field of chemical biology with the field of molecular pharmacology to better investigate receptor-ligand interactions. In future research, different tags may be introduced; for instance, a biotin tag would allow for streptavidin-mediated receptor enrichment followed by LC/MS analysis. Of note, the $\mathrm{A}_{2 \mathrm{~B}} \mathrm{R}$ has been known as the more poorly characterized adenosine receptor subtype. This also has limited the development of molecular probes targeting $\mathrm{A}_{2 \mathrm{~B}} \mathrm{R}$ specifically, in particular for covalently binding ligands, where no case has been reported so far. Covalent probes for $\mathrm{A}_{2 \mathrm{~B}} \mathrm{R}$ and $\mathrm{A}_{3} \mathrm{R}$ may also assist in the structure elucidation of these two adenosine receptor subtypes, which are currently still lacking. 
For decades, scientists have been continuously developing tool compounds to study adenosine receptors. In this endeavor, the use of covalent or reversible probes, whether radiolabeled or fluorescent, has been instrumental (i) to discover new chemical entities, (ii) to characterize and interrogate adenosine receptor subtypes both in vitro and in vivo, and (iii) to study their behavior in physiological and disease conditions. This review has summarized evidence for these applications, but hopefully, it also serves as an invitation to walk another mile to further improve probe characteristics and develop additional tags that allow the investigation of adenosine receptors and other GPCRs in even finer detail.

Funding X Yang is supported by the China Scholarship Council.

\section{Compliance with ethical standards}

Conflicts of interest X Yang declares that she has no conflict of interest. L.H. Heitman declares that she has no conflict of interest.

A.P. IJzerman declares that he has no conflict of interest.

D van der Es declares that he has no conflict of interest.

Ethical approval This article does not contain any studies with human participants or animals performed by any of the authors.

Open Access This article is licensed under a Creative Commons Attribution 4.0 International License, which permits use, sharing, adaptation, distribution and reproduction in any medium or format, as long as you give appropriate credit to the original author(s) and the source, provide a link to the Creative Commons licence, and indicate if changes were made. The images or other third party material in this article are included in the article's Creative Commons licence, unless indicated otherwise in a credit line to the material. If material is not included in the article's Creative Commons licence and your intended use is not permitted by statutory regulation or exceeds the permitted use, you will need to obtain permission directly from the copyright holder. To view a copy of this licence, visit http://creativecommons.org/licenses/by/4.0/.

\section{References}

1. Jacobson KA, Gao ZG (2006) Adenosine receptors as therapeutic targets. Nat Rev Drug Discov 5(3):247-264

2. Jaakola VP, Griffith MT, Hanson MA, Cherezov V, Chien EY, Lane JR, IJzerman AP, Stevens RC (2008) The 2.6 Angstrom crystal structure of a human A2A adenosine receptor bound to an antagonist. Science 322(5905):1211-1217

3. Glukhova A, Thal DM, Nguyen AT, Vecchio EA, Jorg M, Scammells PJ, May LT, Sexton PM, Christopoulos A (2017) Structure of the adenosine A1 receptor reveals the basis for subtype selectivity. Cell 168(5):867-877

4. Gregory KJ, Velagaleti R, Thal DM, Brady RM, Christopoulos A, Conn PJ, Lapinsky DJ (2016) Clickable photoaffinity ligands for metabotropic glutamate receptor 5 based on select acetylenic negative allosteric modulators. ACS Chem Biol 11(7):1870-1879

5. Soethoudt M, Stolze SC, Westphal MV, van Stralen L, Martella A, van Rooden EJ, Guba W, Varga ZV, Deng H, van Kasteren SI,
Grether U, IJzerman AP, Pacher P, Carreira EM, Overkleeft HS, Ioan-Facsinay A, Heitman LH, van der Stelt M (2018) Selective photoaffinity probe that enables assessment of cannabinoid CB2receptor expression and ligand engagement in human cells. J Am Chem Soc 140(19):6067-6075

6. Yang X, Michiels TJM, de Jong C, Soethoudt M, Dekker N, Gordon E, van der Stelt M, Heitman LH, van der Es D, IJzerman AP (2018) An affinity-based probe for the human adenosine A2Areceptor. J Med Chem 61(17):7892-7901

7. Speers AE, Cravatt BF (2004) Profiling enzyme activities in vivo using click chemistry methods. Chem Biol 11(4):535-546

8. Cravatt BF, Wright AT, Kozarich JW (2008) Activity-based protein profiling: from enzyme chemistry to proteomic chemistry. Annu Rev Biochem 77:383-414

9. Flanagan CA (2016) Chapter 10 - GPCR-radioligand binding assays. In: Shukla AK (ed) Methods cell bio. Academic Press, pp 191-215

10. Hulme EC, Trevethick MA (2010) Ligand binding assays at equilibrium: validation and interpretation. Br J Pharmacol 161(6): 1219-1237

11. Klotz KN, Hessling J, Hegler J, Owman C, Kull B, Fredholm BB, Lohse MJ (1998) Comparative pharmacology of human adenosine receptor subtypes-characterization of stably transfected receptors in CHO cells. Naunyn Schmiedeberg's Arch Pharmacol 357(1):19

12. Lane JR, Klaasse E, Lin J, van Bruchem J, Beukers MW, IJzerman AP (2010) Characterization of [3H]LUF5834: a novel non-ribose high-affinity agonist radioligand for the adenosine A1 receptor. Biochem Pharmacol 80(8):1180-1189

13. Beukers MW, Chang LC, von Frijtag Drabbe Kunzel JK, MulderKrieger T, Spanjersberg RF, Brussee J, IJzerman AP (2004) J Med Chem 47(15):3707-3709

14. Wan W, Sutherland GR, Geiger JD (1990) Binding of the adenosine A2receptor ligand [3H]CGS 21680 to human and rat brain: evidence for multiple affinity sites. J Neurochem 55(5):17631771

15. Kim J, Wess J, van Rhee AM, Schoneberg T, Jacobson KA (1995) Site-directed mutagenesis identifies residues involved in ligand recognition in the human $\mathrm{A} 2$ aadenosine receptor. J Biol Chem 270(23):13987-13997

16. Muller CE, Maurinsh J, Sauer R (2000) Binding of [3H]MSX-2 (3-(3-hydroxypropyl)-7-methyl-8-(m-methoxystyryl)-1propargylxanthine) to rat striatal membranes - a new, selective antagonist radioligand for A2A adenosine receptors. Eur J Pharm Sci 10(4):259-265

17. Guo D, Mulder-Krieger T, IJzerman AP, Heitman LH (2012) Functional efficacy of adenosine A2A receptor agonists is positively correlated to their receptor residence time. Br J Pharmacol 166(6): 1846-1859

18. Dionisotti S, Ongini E, Zocchi C, Kull B, Arslan G, Fredholm BB (1997) Characterization of human A2Aadenosine receptors with the antagonist radioligand [3H]-SCH 58261. Br J Pharmacol 121(3):353-360

19. Hinz S, Alnouri WM, Pleiss U, Muller CE (2018) Tritium-labeled agonists as tools for studying adenosine A2B receptors. Purinergic Signal 14:223-233

20. Robeva AS, Woodard RL, Jin XW, Gao ZH, Bhattacharya S, Taylor HE, Rosin DL, Linden J (1996) Molecular characterization of recombinant human adenosine receptors. Drug Dev Res 39(34):243-252

21. Linden J, Thai T, Figler H, Jin X, Robeva AS (1999) Characterization of human $\mathrm{A}(2 \mathrm{~B})$ adenosine receptors: radioligand binding, western blotting, and coupling to $\mathrm{G}(\mathrm{q})$ in human embryonic kidney 293 cells and HMC-1 mast cells. Mol Pharmacol 56(4):705-713 
22. Ji XD, Kim YC, Ahern DG, Linden J, Jacobson KA (2001) [3H]MRS 1754, a selective antagonist radioligand for A2B adenosine receptors. Biochem Pharmacol 61(6):657-663

23. Baraldi PG, Tabrizi MA, Preti D, Bovero A, Fruttarolo F, Romagnoli R, Moorman AR, Gessi S, Merighi S, Varani K, Borea PA (2004) [3H]-MRE 2029-F20, a selective antagonist radioligand for the human $\mathrm{A} 2 \mathrm{~B}$ adenosine receptors. Bioorg Med Chem Lett 14(13):3607-3610

24. Stewart M, Steinig AG, Ma CL, Song JP, McKibben B, Castelhano AL, MacLennan SJ (2004) [3H]OSIP339391, a selective, novel, and high affinity antagonist radioligand for adenosine A2B receptors. Biochem Pharmacol 68(2):305-312

25. Borrmann T, Hinz S, Lertarelli DCG, Li WJ, Florin NC, Scheiff AB, Muller CE (2009) 1-Alkyl-8-(piperazine-1sulfonyl)phenylxanthines: development and characterization of adenosine A2Breceptor antagonists and a new radioligand with subnanomolar affinity and subtype specificity. J Med Chem 52(13):3994-4006

26. Olah ME, Gallorodriguez C, Jacobson KA, Stiles GL (1994) 125I4-aminobenzyl-5'-N-methylcarboxamidoadenosine, a high affinity radioligand for the rat A3 adenosine receptor. Mol Pharmacol 45(5):978-982

27. Lane JR, Beukers MW, Mulder-Krieger T, IJzerman AP (2010) The endocannabinoid 2-arachidonylglycerol is a negative allosteric modulator of the human $\mathrm{A} 3$ adenosine receptor. Biochem Pharmacol 79(1):48-56

28. Klotz KN, Falgner N, Kachler S, Lambertucci C, Vittori S, Volpini R, Cristalli G (2007) [3H]HEMADO - a novel tritiated agonist selective for the human adenosine A3 receptor. Eur J Pharmacol 556(1-3):14-18

29. Gao ZG, Teng B, Wu HT, Joshi BV, Griffiths GL, Jacobson KA (2009) Synthesis and pharmacological characterization of [125I]MRS1898, a high-affinity, selective radioligand for the rat A3 adenosine receptor. Purinergic Signal 5(1):31-37

30. Auchampach JA, Gizewski ET, Wan TC, de Castro S, Brown GG, Jacobson KA (2010) Synthesis and pharmacological characterization of [125I]MRS5127, a high affinity, selective agonist radioligand for the A3 adenosine receptor. Biochem Pharmacol 79(7):967-973

31. Varani K, Merighi S, Gessi S, Klotz KN, Leung E, Baraldi PG, Cacciari B, Romagnoli R, Spalluto G, Borea PA (2000) Mol Pharmacol 57(5):968-975

32. Muller CE, Diekmann M, Thorand M, Ozola V (2002) [3H]8Ethyl-4-methyl-2-phenyl-(8R)-4,5,7,8-tetrahydro-1H-imidazo[2, 1-i]-purin-5-one ([3H]PSB-11), a novel high-affinity antagonist radioligand for human A3 adenosine receptors. Bioorg Med Chem Lett 12(3):501-503

33. Klotz KN, Lohse MJ, Schwabe U, Cristalli G, Vittori S, Grifantini M (1989) 2-Chloro-N6-[3H]cyclopentyladenosine ([3H]CCPA)? A high affinity agonist radioligand for A1 adenosine receptors. Naunyn Schmiedeberg's Arch Pharmacol 340(6):679-683

34. Lohse MJ, Klotz KN, Lindenbornfotinos J, Reddington M, Schwabe U, Olsson RA (1987) 8-Cyclopentyl-1,3dipropylxanthine (DPCPX)? A selective high affinity antagonist radioligand for A1 adenosine receptors. Naunyn Schmiedeberg's Arch Pharmacol 336(2):204-210

35. Xia L, de Vries H, IJzerman AP, Heitman LHH (2016) Scintillation proximity assay (SPA) as a new approach to determine a ligand's kinetic profile. A case in point for the adenosine A1 receptor. Purinergic Signal 12(1):115-126

36. Jarvis MF, Schulz R, Hutchison AJ, Do UH, Sills MA, Williams M (1989) [3H]CGS 21680, a selective A2 adenosine receptor agonist directly labels A2 receptors in rat brain. J Pharmacol Exp Ther 251(3):888-893

37. Svenningsson P, Hall H, Sedvall G, Fredholm BB (1997) Distribution of adenosine receptors in the postmortem human brain: an extended autoradiographic study. Synapse. 27(4):322335

38. Kurumaji A, Toru M (1998) An increase in [3H] CGS21680 binding in the striatum of postmortem brains of chronic schizophrenics. Brain Res 808(2):320-323

39. Lindstrom K, Ongini E, Fredhohn BB (1996) The selective adenosine $\mathrm{A} 2 \mathrm{~A}$ receptor antagonist $\mathrm{SCH} 58261$ discriminates between two different binding sites for [3H]-CGS 21680 in the rat brain. Naunyn Schmiedeberg's Arch Pharmacol 354(4):539-541

40. Sihver W, Schulze A, Wutz W, Stusgen S, Olsson RA, Bier D, Holschbach MH (2009) Autoradiographic comparison of in vitro binding characteristics of various tritiated adenosine $\mathrm{A} 2 \mathrm{~A}$ receptor ligands in rat, mouse and pig brain and first ex vivo results. Eur J Pharmacol 616(1-3):107-114

41. Hockemeyer J, Burbiel JC, Muller CE (2004) Multigram-scale syntheses, stability, and photoreactions of A2Aadenosine receptor antagonists with 8-styrylxanthine structure: potential drugs for Parkinson's disease. J Org Chem 69(10):3308-3318

42. Alexander SPH, Millns PJ (2001) [3H]ZM241385 - an antagonist radioligand for adenosine $\mathrm{A} 2 \mathrm{~A}$ receptors in rat brain. Eur $\mathrm{J}$ Pharmacol 411(3):205-210

43. Ji XD, Jacobson KA (1999) Use of the triazolotriazine [3H]ZM 241385 as a radioligand at recombinant human A2B adenosine receptors. Drug Des Discov Nov 16(3):217-26

44. El Yacoubi M, Ledent C, Parmentier M, Ongini E, Costentin J, Vaugeois JM (2001) In vivo labelling of the adenosine A2Areceptor in mouse brain using the selective antagonist [3H]SCH 58261. Eur J Neurosci 14(9):1567-1570

45. Bryant R, McGuinness D, Turek-Etienne T, Guyer D, Yu LM, Howells L, Caravano J, Zhai Y, Lachowicz J (2004) WGA-coated yttrium oxide beads enable an imaging-based adenosine 2 a receptor binding scintillation proximity assay suitable for high throughput screening. Assay Drug Dev Technol 2(3):290-299

46. Casado V, Casillas T, Mallol J, Canela EI, Lluis C, Franco R (1992) The adenosine receptors present on the plasma membrane of chromaffin cells are of the A2bsubtype. J Neurochem 59(2): 425-431

47. Bosch MP, Campos F, Niubo I, Rosell G, Diaz JL, Brea J, Loza MI, Guerrero A (2004) Synthesis and biological activity of new potential agonists for the human adenosine A2Areceptor. J Med Chem 47(16):4041-4053

48. Gessi S, Varani K, Merighi S, Cattabriga E, Pancaldi C, Szabadkai Y, Rizzuto R, Klotz KN, Leung E, Mac LS, Baraldi PG, Borea PA (2005) Expression, pharmacological profile, and functional coupling of A2Breceptors in a recombinant system and in peripheral blood cells using a novel selective antagonist radioligand, [3H]MRE 2029-F20. Mol Pharmacol 67(6):2137-2147

49. Zhou QY, Li C, Olah ME, Johnson RA, Stiles GL, Civelli O (1992) Molecular cloning and characterization of an adenosine receptor: the A3 adenosine receptor. Proc Natl Acad Sci U S A 89(16):7432-7436

50. Baraldi PG, Cacciari B, Romagnoli R, Varani K, Merighi S, Gessi S, Borea PA, Leung E, Hickey SL, Spalluto G (2000) Synthesis and preliminary biological evaluation of [3H]-MRE 3008-F20: the first high affinity radioligand antagonist for the human A3 adenosine receptors. Bioorg Med Chem Lett 10(3):209-211

51. Mishina M, Ishiwata K (2014) Adenosine receptor PET imaging in human brain. Int Rev Neurobiol 119:51-69 
52. Khanapur S, Waarde A, Ishiwata K, Leenders KL, Dierckx RA, Elsinga PH (2014) Curr Med Chem 21(3):312-328

53. van Waarde A, Dierckx R, Zhou X, Khanapur S, Tsukada H, Ishiwata K, Luurtsema G, de Vries EFJ, Elsinga PH (2018) Potential therapeutic applications of adenosine A2Areceptor ligands and opportunities for A2Areceptor imaging. Med Res Rev 38(1):5-56

54. Guo M, Gao Z-G, Tyler R, Stodden T, Li Y, Ramsey J, Zhao W-J, Wang G-J, Wiers CE, Fowler JS, Rice KC, Jacobson KA, Kim SW, Volkow ND (2018) Preclinical evaluation of the first adenosine A1receptor partial agonist radioligand for positron emission tomography imaging. J Med Chem 61(22):9966-9975

55. Ishiwata K, Ogi N, Shimada J, Nonaka H, Tanaka A, Suzuki F, Senda M (2000) Further characterization of a CNS adenosine A2a receptor ligand $[11 \mathrm{C}] \mathrm{KF} 18446$ within vitro autoradiography andin vivo tissue uptake. Ann Nucl Med 14(2):81-89

56. Todde S, Moresco RM, Simonelli F, Baraldi PG, Cacciari B, Spalluto G, Varani K, Monopoli A, Matarrese M, Carpinelli A, Magni F, Kienle MG, Fazio F (2000) Design, radiosynthesis, and biodistribution of a new potent and selective ligand for in vivo imaging of the adenosine A2Areceptor system using positron emission tomography. J Med Chem 43(23):4359-4362

57. Neustadt BR, Hao J, Lindo N, Greenlee WJ, Stamford AW, Tulshian D, Ongini E, Hunter J, Monopoli A, Bertorelli R, Foster C, Arik L, Lachowicz J, Ng K, Feng K-I (2007) Potent, selective, and orally active adenosine $\mathrm{A} 2 \mathrm{~A}$ receptor antagonists: arylpiperazine derivatives of pyrazolo[4,3-e]-1,2,4-triazolo[1,5c]pyrimidines. Bioorg Med Chem Lett 17(5):1376-1380

58. Shinkre BA, Kumar TS, Gao ZG, Deflorian F, Jacobson KA, Trenkle WC (2010) Synthesis and evaluation of 1,2,4-triazolo[1, 5-c]pyrimidine derivatives as A2A receptor-selective antagonists. Bioorg Med Chem Lett 20(19):5690-5694

59. Kumar TS, Mishra S, Deflorian F, Yoo LS, Phan K, Kecskes M, Szabo A, Shinkre B, Gao ZG, Trenkle W, Jacobson KA (2011) Molecular probes for the A2A adenosine receptor based on a pyrazolo[4,3-e][1,2,4]triazolo[1,5-c]pyrimidin-5-amine scaffold. Bioorg Med Chem Lett 21(9):2740-2745

60. Vala C, Morley TJ, Zhang X, Papin C, Tavares AA, Lee HS, Constantinescu C, Barret O, Carroll VM, Baldwin RM, Tamagnan GD, Alagille D (2016) Synthesis and in vivo evaluation of fluorine-18 and iodine-123 pyrazolo[4,3-e]-1,2,4triazolo[1,5-c]pyrimidine derivatives as PET and SPECT radiotracers for mapping A2Areceptors. ChemMedChem. 11(17): 1936-1943

61. Petroni D, Giacomelli C, Taliani S, Barresi E, Robello M, Daniele S, Bartoli A, Burchielli S, Pardini S, Salvadori PA, Da Settimo F, Martini C, Trincavelli ML, Menichetti L (2016) Toward PET imaging of A2B adenosine receptors: a carbon-11 labeled triazinobenzimidazole tracer. Nucl Med Biol 43(5):309-317

62. Lindemann M, Hinz S, Deuther-Conrad W, Namasivayam V, Dukic-Stefanovic S, Teodoro R, Toussaint M, Kranz M, Juhl C, Steinbach J, Brust P, Muller CE, Wenzel B (2018) Radiosynthesis and in vivo evaluation of a fluorine-18 labeled pyrazine based radioligand for PET imaging of the adenosine A2B receptor. Bioorg Med Chem 26(16):4650-4663

63. Balber T., Singer J., Berroteran-Infante N., Dumanic M., Fetty L., Fazekas-Singer J., Vraka C., Nics L., Bergmann M., Pallitsch K., Spreitzer H., Wadsak W., Hacker M., Jensen-Jarolim E., Viernstein H., and Mitterhauser M. Contrast media mol imaging. 2018

64. Kiesewetter DO, Lang L, Ma Y, Bhattacharjee AK, Gao Z-G, Joshi BV, Melman A, de Castro S, Jacobson KA (2009)
Synthesis and characterization of [76Br]-labeled high-affinity A3 adenosine receptor ligands for positron emission tomography. Nucl Med Biol 36(1):3-10

65. Paul S, Elsinga PH, Ishiwata K, Dierckx RAJO, van Waarde A (2011) Adenosine A1 receptors in the central nervous system: their functions in health and disease, and possible elucidation by PET imaging. Curr Med Chem 18(31):4820-4835

66. Fukumitsu N, Ishii K, Kimura Y, Oda K, Sasaki T, Mori Y, Ishiwata K (2005) J Nucl Med 46(1):32-37

67. Bauer A, Holschbach MH, Meyer PT, Boy C, Herzog H, Olsson RA, Coenen HH, Zilles K (2003) In vivo imaging of adenosine A1 receptors in the human brain with [18F]CPFPX and positron emission tomography. Neuroimage. 19(4):1760-1769

68. Meyer PT, Elmenhorst D, Boy C, Winz O, Matusch A, Zilles K, Bauer A (2007) Effect of aging on cerebral A1 adenosine receptors: a [18F]CPFPX PET study in humans. Neurobiol Aging 28(12):1914-1924

69. Elmenhorst D, Elmenhorst EM, Hennecke E, Kroll T, Matusch A, Aeschbach D, Bauer A (2017) Recovery sleep after extended wakefulness restores elevated A1adenosine receptor availability in the human brain. Proc Natl Acad Sci USA 114(16):4243-4248

70. Elmenhorst D, Meyer PT, Matusch A, Winz OH, Bauer A (2012) Caffeine occupancy of human cerebral A1 adenosine receptors: in vivo quantification with $18 \mathrm{~F}-\mathrm{CPFPX}$ and PET. J Nucl Med 53(11):1723-1729

71. Mishina M, Ishii K, Kimura Y, Suzuki M, Kitamura S, Ishibashi K, Sakata M, Oda K, Kobayashi S, Kimura K, Ishiwata K (2017) Synapse.:71(8)

72. Matusch A, Saft C, Elmenhorst D, Kraus PH, Gold R, Hartung HP, Bauer A (2014) Cross sectional PET study of cerebral adenosine A1 receptors in premanifest and manifest Huntington's disease. Eur J Nucl Med Mol Imaging 41(6):1210-1220

73. Mishina M, Ishiwata K, Naganawa M, Kimura Y, Kitamura S, Suzuki M, Hashimoto M, Ishibashi K, Oda K, Sakata M, Hamamoto M, Kobayashi S, Katayama Y, Ishii K (2011) PLoS One 6(2): 17338

74. Mishina M, Ishiwata K, Kimura Y, Naganawa M, Oda K, Kobayashi S, Katayama Y, Ishii K (2007) Evaluation of distribution of adenosine A2A receptors in normal human brain measured with [11C]TMSX PET. Synapse. 61(9):778-784

75. Ramlackhansingh AF, Bose SK, Ahmed I, Turkheimer FE, Pavese N, Brooks DJ (2011) Adenosine 2A receptor availability in dyskinetic and nondyskinetic patients with Parkinson disease. Neurology. 76(21):1811-1816

76. Moresco RM, Todde S, Belloli S, Simonelli P, Panzacchi A, Rigamonti M, Galli-Kienle M, Fazio F (2005) In vivo imaging of adenosine $\mathrm{A} 2 \mathrm{~A}$ receptors in rat and primate brain using [11C]SCH442416. Eur J Nucl Med Mol Imaging 32(4):405-413

77. Zhou X, Khanapur S, Huizing AP, Zijlma R, Schepers M, Dierckx RA, van Waarde A, de Vries EF, Elsinga PH (2014) Synthesis and preclinical evaluation of 2-(2-furanyl)-7-[2-[4-[4-(2[11C]methoxyethoxy)phenyl]-1 - piperazinyl]ethyl] $7 \mathrm{H}$ pyrazolo $[4,3$-e $][1,2,4]$ triazolo $[1,5$-c]pyrimidine-5-amine ([11C]preladenant) as a PET tracer for the imaging of cerebral adenosine A2Areceptors. J Med Chem 57(21):9204-9210

78. Ishibashi K, Miura Y, Wagatsuma K, Toyohara J, Ishiwata K, Ishii $\mathrm{K}$ (2018) Occupancy of adenosine A2A receptors by istradefylline in patients with Parkinson's disease using 11C-preladenant PET. Neuropharmacology 143:106-112

79. Khanapur S, Paul S, Shah A, Vatakuti S, Koole MJB, Zijlma R, Dierckx RAJO, Luurtsema G, Garg P, van Waarde A, Elsinga PH (2014) Development of [18F]-labeled pyrazolo[4,3-e]-1,2,4- 
triazolo[1,5-c]pyrimidine (SCH442416) analogs for the imaging of cerebral adenosine A2Areceptors with positron emission tomography. J Med Chem 57(15):6765-6780

80. Tavares AA, Batis JC, Papin C, Jennings D, Alagille D, Russell DS, Vala C, Lee H, Baldwin RM, Zubal IG, Marek KL, Seibyl JP, Barret O, Tamagnan GD (2013) Kinetic modeling, test-retest, and dosimetry of 123I-MNI-420 in humans. J Nucl Med 54(10):1760 1767

81. Barret O, Hannestad J, Vala C, Alagille D, Tavares A, Laruelle M, Jennings D, Marek K, Russell D, Seibyl J, Tamagnan $\mathrm{G}$ (2015) Characterization in humans of $18 \mathrm{~F}$ MNI-444, a PET radiotracer for brain adenosine 2A receptors. J Nucl Med 56(4):586-591

82. Li A-H, Moro S, Forsyth N, Melman N, Ji X.-d., and Jacobson K.A. (1999) Synthesis, CoMFA analysis, and receptor docking of 3,5-diacyl-2,4-dialkylpyridine derivatives as selective A3adenosine receptor antagonists. J Med Chem 42(4):706-721

83. Wadsak W, Mien L-K, Shanab K, Ettlinger DE, Haeusler D, Sindelar K, Lanzenberger RR, Spreitzer H, Viernstein H, Keppler BK, Dudczak R, Kletter K, Mitterhauser M (2008) Preparation and first evaluation of [18F]FE@SUPPY: a new PET tracer for the adenosine A3 receptor. Nucl Med Biol 35(1): 61-66

84. Mitterhauser M, Haeusler D, Mien L-K, Ungersboeck J, Nics L, Lanzenberger RR, Sindelar K, Viernstein H, Dudczak R, Kletter K (2009) Automatisation and first evaluation of [18F]FE@SUPPY: 2, an alternative PET-tracer for the adenosine A3 receptor: a comparison with [18F]FE@SUPPY. Open Nucl Med J 1:15-23

85. Soave M, Briddon SJ, Hill SJ, Stoddart LA (2020) Fluorescent ligands: bringing light to emerging GPCR paradigms. Br J Parmacol 177:978-991

86. Kozma E, Jayasekara PS, Squarcialupi L, Paoletta S, Moro S, Federico S, Spalluto G, Jacobson KA (2013) Fluorescent ligands for adenosine receptors. Bioorg Med Chem 23(1):26-36

87. Stoddart LA, Vernall AJ, Denman JL, Briddon SJ, Kellam B, Hill SJ (2012) Fragment screening at adenosine-A3 receptors in living cells using a fluorescence-based binding assay. Chem Biol 19(9): 1105-1115

88. Arruda MA, Stoddart LA, Gherbi K, Briddon SJ, Kellam B, Hill SJ (2017) A non-imaging high throughput approach to chemical library screening at the unmodified adenosine-A3 receptor in living cells. Front Pharmacol 8:908

89. Briddon SJ, Middleton RJ, Cordeaux Y, Flavin FM, Weinstein JA, George MW, Kellam B, Hill SJ (2004) Quantitative analysis of the formation and diffusion of A1-adenosine receptor-antagonist complexes in single living cells. Proc Natl Acad Sci U S A 101(13):4673-4678

90. Cooper SL, Soave M, Jorg M, Scammells PJ, Woolard J, Hill SJ (2019) Probe dependence of allosteric enhancers on the binding affinity of adenosine A1-receptor agonists at rat and human A1receptors measured using NanoBRET. Br J Pharmacol 176(7): 864-878

91. McCabe RT, Skolnick P, Jacobson KA (1992) 2-[2-[4-[2-[2-[1,3Dihydro-1, 1 - bis ( 4 - hydrox y p henyl) - 3 - ox o - 5 isobenzofuranthioureidyl]ethylaminocarbonyl] ethyl]phenyl] ethylamino]-5?-N-ethylcarboxamidoadenosine (FITC-APEC): a fluorescent ligand for A2a-adenosine receptors. J Fluoresc 2(4): 217-223

92. McNeely PM, Naranjo AN, Forsten-Williams K, Robinson AS (2017) $\mathrm{A}_{2 \mathrm{~A}} \mathrm{R}$ binding kinetics in the ligand depletion regime. Slas Discov 22(2):166-175
93. Duroux R, Ciancetta A, Mannes P, Yu JH, Boyapati S, Gizewski E, Yous S, Ciruela F, Auchampach JA, Gao ZG, Jacobson KA (2017) Bitopic fluorescent antagonists of the A2Aadenosine receptor based on pyrazolo[4,3-e][1,2,4]triazolo[1,5-c]pyrimidin-5amine functionalized congeners. Medchemcomm. 8(8):16591667

94. Comeo E, Kindon ND, Soave M, Stoddart LA, Kilpatrick LE, Scammells PJ, Hill SJ, Kellam BJ (2019) Subtype-selective fluorescent ligands as pharmacological research tools for the human adenosine A2Areceptor. Med Chem 63:2656-2672. https://doi. org/10.1021/acs.jmedchem.9b01856

95. Kose M, Gollos S, Karcz T, Fiene A, Heisig F, Behrenswerth A, Kiec-Kononowicz K, Namasivayam V, Muller CE (2018) Fluorescent-labeled selective adenosine A2Breceptor antagonist enables competition binding assay by flow cytometry. J Med Chem 61(10):4301-4316

96. Barresi E, Giacomelli C, Daniele S, Tonazzini I, Robello M, Salerno S, Piano I, Cosimelli B, Greco G, Da Settimo F, Martini C, Trincavelli ML, Taliani S (2018) Bba-Biomembranes. 26(22): $5885-5895$

97. Vernall AJ, Stoddart LA, Briddon SJ, Ng HW, Laughton CA, Doughty SW, Hill SJ, Kellam B (2013) Conversion of a nonselective adenosine receptor antagonist into A3-selective high affinity fluorescent probes using peptide-based linkers. Org Biomol Chem 11(34):5673-5682

98. Bouzo-Lorenzo M, Stoddart LA, Xia L, IJzerman AP, Heitman LH, Briddon SJ, Hill SJ (2019) A live cell NanoBRET binding assay allows the study of ligand-binding kinetics to the adenosine A3 receptor. Purinergic Signal 15:139-153

99. Kozma E, Kumar TS, Federico S, Phan K, Balasubramanian R, Gao ZG, Paoletta S, Moro S, Spalluto G, Jacobson KA (2012) Novel fluorescent antagonist as a molecular probe in A3 adenosine receptor binding assays using flow cytometry. Biochem Pharmacol 83(11):1552-1561

100. Federico S, Margiotta E, Moro S, Kozma E, Gao Z-G, Jacobson KA, Spalluto G (2020) Conjugable A3 adenosine receptor antagonists for the development of functionalized ligands and their use in fluorescent probes. Eur J Med Chem 186:111886

101. Fernandez-Duenas V, Gomez-Soler M, Jacobson KA, Kumar ST, Fuxe K, Borroto-Escuela DO, Ciruela F (2012) Molecular determinants of A2AR-D2R allosterism: role of the intracellular loop 3 of the D2R. J Neurochem 123(3):373-384

102. Fernandez-Duenas V, Gomez-Soler M, Morato X, Nunez F, Das A, Kumar TS, Jauma S, Jacobson KA, Ciruela F (2013) Dopamine $\mathrm{D} 2$ receptor-mediated modulation of adenosine $\mathrm{A} 2 \mathrm{~A}$ receptor agonist binding within the A2AR/D2R oligomer framework. Neurochem Int 63(1):42-46

103. Corriden R, Self T, Akong-Moore K, Nizet V, Kellam B, Briddon SJ, Hill SJ (2013) Adenosine-A3receptors in neutrophil microdomains promote the formation of bacteria-tethering cytonemes. EMBO Rep 14(8):726-732

104. Stoddart LA, Vernall AJ, Briddon SJ, Kellam B, Hill SJ (2015) Direct visualisation of internalization of the adenosine $\mathrm{A} 3$ receptor and localization with arrestin 3 using a fluorescent agonist. Neuropharmacology. 98:68-77

105. Jorg M, Scammells PJ (2016) Guidelines for the synthesis of small-molecule irreversible probes targeting $\mathrm{G}$ protein-coupled receptors. ChemMedChem. 11(14):1488-1498

106. Adeniyi AA, Muthusamy R, Soliman ME (2016) New drug design with covalent modifiers. Expert Opin Drug Discov. 11(1):7990 
107. Robinette D, Neamati N, Tomer KB, Borchers CH (2006) Expert Rev Proteomics. 3(4):399-408

108. Grunbeck A, Sakmar TP (2013) Probing G protein-coupled receptor-ligand interactions with targeted photoactivatable cross-linkers. Biochemistry 52(48):8625-8632

109. Dorman G, Prestwich GD (2000) Using photolabile ligands in drug discovery and development. Trends Biotechnol 18(2):64-77

110. Morey TE, Belardinelli L, Dennis DM (1998) Validation of Furchgott's method to determine agonist-dependent A1-adenosine receptor reserve in guinea-pig atrium. Br J Pharmacol 123(7):1425-1433

111. Yasunaga T, Motoyama S, Nose T, Kodama H, Kondo M, Shimohigashi Y (1996) J Biol Chem 120(2):459-465

112. Weichert D, Gmeiner P (2015) Covalent molecular probes for class A G protein-coupled receptors: advances and applications. ACS Chem Biol 10(6):1376-1386

113. Stiles GL, Daly DT, Olsson RA (1985) J Biol Chem 33(2):A231A231

114. Patel A, Craig RH, Daluge SM, Linden J (1988) 125I-BWA844U, an antagonist radioligand with high affinity and selectivity for adenosine A1 receptors, and 125I-azido-BW-A844U, a photoaffinity label. Mol Pharmacol 33:585-591

115. Jacobson KA, Barone S, Kammula U, Stiles GL (1989) Electrophilic derivatives of purines as irreversible inhibitors of A1 adenosine receptors. J Med Chem 32(5):1043-1051

116. Yang X, Dilweg MA, Osemwengie D, Burggraaff L, van der Es D, Heitman LH, IJzerman AP (2020) Biochem Pharmacol 180: 114144

117. Beauglehole AR, Baker SP, Scammells PJ (2000) Fluorosulfonylsubstituted xanthines as selective irreversible antagonists for the A1-adenosine receptor. J Med Chem 43(26):4973-4980

118. Barrington WW, Jacobson KA, Stiles GL (1990) Mol Pharmacol 38(2):177-183

119. Luthin DR, Lee KS, Okonkwo D, Zhang PJ, Linden J (1995) Photoaffinity labeling with 2(-)[2-(4-azido-3(-)[125I]iodophenyl)ethylamino]adenosine and autoradiography with 2()[2-(4-amino-3(-)[125I]iodophenyl)ethylamino]adenosine of A2a adenosine receptors in rat brain. J Neurochem 65(5):2072-2079

120. Muranaka H, Momose T, Handa C, Ozawa T (2017) Photoaffinity labeling of the human A2Aadenosine receptor and cross-link position analysis by mass spectrometry. ACS Med Chem Lett 8(6): 660-665

121. Jacobson KA, Pannell LK, Ji XD, Jarvis MF, Williams M, Hutchison AJ, Barrington WW, Stiles GL (1989) Agonist derived molecular probes for A2 adenosine receptors. J Mol Recognit 2(4):170-178

122. Moss SM, Jayasekara PS, Paoletta S, Gao ZG, Jacobson KA (2014) Structure-based design of reactive nucleosides for sitespecific modification of the A2Aadenosine receptor. ACS Med Chem Lett 5(9):1043-1048

123. Ji XD, Gallo-Rodriguez C, Jacobson KA (1993) 8-(3Isothiocyanatostyryl)caffeine is a selective, irreversible inhibitor of striatal A2-adenosine receptors. Drug Dev Res 29(4):292-298

124. Yang X, Dong G, Michiels TJM, Lenselink EB, Heitman L, Louvel J, IJzerman AP (2017) A covalent antagonist for the human adenosine A2A receptor. Purinergic Signal 13(2):191-201

125. Ji XD, Gallo-Rodriguez C, Jacobson KA (1994) A selective agonist affinity label for A3 adenosine receptors. Biochem Biophys Res Commun 203(1):570-576

126. Li AH, Chang L, Ji X, Melman N, Jacobson KA (1999) Functionalized congeners of 1,4-dihydropyridines as antagonist molecular probes for A3adenosine receptors. Bioconjug Chem 10(4):667-677

127. Baraldi PG, Cacciari B, Moro S, Romagnoli R, Ji X, Jacobson KA, Gessi S, Borea PA, Spalluto G (2001) Fluorosulfonyl- and bis-( $\beta$-chloroethyl)amino-phenylamino functionalized pyrazolo[4,3-e]1,2,4-triazolo[1,5-c]pyrimidine derivatives: irreversible antagonists at the human A3adenosine receptor and molecular modeling studies. J Med Chem 44(17):2735-2742

128. Yang X, van Veldhoven JPD, Offringa J, Kuiper BJ, Lenselink EB, Heitman LH, van der Es D, IJzerman AP (2019) Development of covalent ligands for $\mathrm{G}$ protein-coupled receptors: a case for the human adenosine A3receptor. J Med Chem 62(7):3539-3552

129. Klotz KN, Cristalli G, Grifantini M, Vittori S, Lohse MJ (1985) J Biol Chem 260(27):4659-4664

130. Lohse MJ, Klotz KN, Schwabe U (1986) Agonist photoaffinity labeling of A1 adenosine receptors: persistent activation reveals spare receptors. Mol Pharmacol 30(4):403-409

131. Lohse MJ, Klotz KN, Schwabe U (1991) Mol Pharmacol 39(4): 517-523

132. Earl CQ, Patel A, Craig RH, Daluge SM, Linden J (1988) Photoaffinity labeling adenosine A1 receptors with an antagonist iodine-125-labeled aryl azide derivative of 8-phenylxanthine. J Med Chem 31(4):752-756

133. Kennedy AP, Mangum KC, Linden J, Wells JN (1996) Mol Pharmacol 50(4):789-798

134. Jorg M, Glukhova A, Abdul-Ridha A, Vecchio EA, Nguyen ATN, Sexton PM, White PJ, May LT, Christopoulos A, Scammells PJ (2016) Novel irreversible agonists acting at the Aladenosine receptor. J Med Chem 59(24):11182-11194

135. Zhang J, Belardinelli L, Jacobson KA, Otero DH, Baker SP (1997) Persistent activation by and receptor reserve for an irreversible A1adenosine receptor agonist in DDT1MF-2 cells and in guinea pig heart. Mol Pharmacol 52(3):491-498

136. Stiles GL, Jacobsen KJ (1988) High affinity acylating antagonists for the A1 adenosine receptor: identification of binding subunit. Mol Pharmacol 34(6):724-728

137. Dennis D, Jacobson K, Belardinelli L (1992) Am J Phys 262(3 Pt 2):661-671

138. Scammells PJ, Baker SP, Belardinelli L, Olsson RA (1994) Substituted 1,3-dipropylxanthines as irreversible antagonists of A1 adenosine receptors. J Med Chem 37(17):2704-2712

139. Gesztelyi R, Kiss Z, Wachal Z, Juhasz B, Bombicz M, Csepanyi E, Pak K, Zsuga J, Papp C, Galajda Z, Branzaniuc K, Porszasz R, Szentmiklosi AJ, Tosaki A (2013) The surmountable effect of FSCPX, an irreversible A1 adenosine receptor antagonist, on the negative inotropic action of A1 adenosine receptor full agonists in isolated guinea pig left atria. Arch Pharm Res 36(3):293-305

140. van Muijlwijk-Koezen JE, Timmerman H, van der Sluis RP, van de Stolpe AC, Menge WM, Beukers MW, van der Graaf PH, de Groote M, IJzerman AP (2001) Synthesis and use of FSCPX, an irreversible adenosine A1 antagonist, as a 'receptor knock-down' tool. Bioorg Med Chem Lett 11(6):815-818

141. Beauglehole AR, Baker SP, Scammells PJ (2002) New irreversible adenosine A1 antagonists based on FSCPX. Bioorg Med Chem Lett 12(21):3179-3182

142. Barrington WW, Jacobson KA, Hutchison AJ, Williams M, Stiles GL (1989) Identification of the A2 adenosine receptor binding subunit by photoaffinity crosslinking. Proc Natl Acad Sci U S A 86(17):6572-6576

143. Piersen CE, True CD, Wells JN (1994) Mol Pharmacol 45(5): $871-877$ 
144. Baraldi PG, Cacciari B, Spalluto G, Pineda de las Infantas y Villatoro MJ, Zocchi C, Dionisotti S, Ongini E (1996) J Med Chem 39(5):1164-1171

145. Jacobson KA, Stiles GL, Ji XD (1992) Mol Pharmacol 42(1):123133

146. Niiya K, Jacobson KA, Silvia SK, Olsson RA (1993) Covalent binding of a selective agonist irreversibly activates guinea pig coronary artery A2 adenosine receptors. N-S Arch Pharmacol 347(5):521-526

147. Shryock JC, Snowdy S, Baraldi PG, Cacciari B, Spalluto G, Monopoli A, Ongini E, Baker SP, Belardinelli L (1998) A2AAdenosine receptor reserve for coronary vasodilation. Circulation. 98(7):711-718

148. Iliopoulos-Tsoutsouvas C, Kulkarni RN, Makriyannis A, Nikas SP (2018) Fluorescent probes for G-protein-coupled receptor drug discovery. Expert Opin Drug Discov 13(10):933-947

149. Ma Z, Lin Y, Cheng Y, Wu W, Cai R, Chen S, Shi B, Han B, Shi X, Zhou Y, Du L, Li M (2016) Discovery of the first environmentsensitive near-infrared (NIR) fluorogenic ligand for $\alpha 1$-adrenergic receptors imaging in vivo. J Med Chem 59(5):2151-2162

150. Zhang SJ, Shao P, Bai MF (2013) In vivo type 2 cannabinoid receptor-targeted tumor optical imaging using a near infrared fluorescent probe. Bioconjug Chem 24(11):1907-1916
Publisher's note Springer Nature remains neutral with regard to jurisdictional claims in published maps and institutional affiliations.

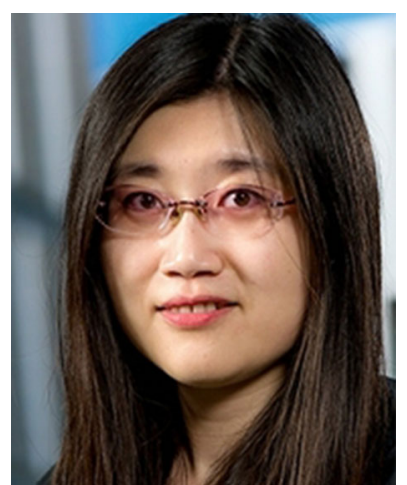

Xue Yang received her graduate diploma from China Pharmaceutical University and her $\mathrm{PhD}$ from Leiden University. Throughout her $\mathrm{PhD}$ studies she mainly focused on the design and evaluation of pharmacological tools targeting adenosine receptors. She is currently a research scientist at AstraZeneca responsible for compound profiling and mechanism of action studies. 